in vivo $31: 1-22(2017)$

doi:10.21873/invivo.11019

Review

\title{
Pathophysiological Mechanisms of Renal Fibrosis: A Review of Animal Models and Therapeutic Strategies
}

\author{
ANTÓNIO NOGUEIRA ${ }^{1,2}$, MARIA JOÃO PIRES ${ }^{1,3}$ and PAULA ALEXANDRA OLIVEIRA ${ }^{1,3}$ \\ ${ }^{1}$ Center for the Research and Technology of Agro-Environmental and Biological Sciences, and \\ ${ }^{3}$ Department of Veterinary Sciences, University of Trás-os-Montes and Alto Douro, Vila Real, Portugal; \\ ${ }^{2}$ Department of Therapeutic and Diagnostic Technologies, Polytechnic Institute of Bragança, Bragança, Portugal
}

\begin{abstract}
Chronic kidney disease (CKD) is a long-term condition in which the kidneys do not work correctly. It has a high prevalence and represents a serious hazard to human health and estimated to affects hundreds of millions of people. Diabetes and hypertension are the two principal causes of CKD. The progression of CKD is characterized by the loss of renal cells and their replacement by extracellular matrix (ECM), independently of the associated disease. Thus, one of the consequences of CKD is glomerulosclerosis and tubulointerstitial fibrosis caused by an imbalance between excessive synthesis and reduced breakdown of the ECM. There are many molecules and cells that are associated with progression of renal fibrosis e.g. angiotensin II (Ang II). Therefore, in order to understand the biopathology of renal fibrosis and for the evaluation of new treatments, the use of animal models is crucial such as: surgical, chemical and physical models, spontaneous models, genetic models and in vitro models. However, there are currently no effective treatments for preventing the progression of renal fibrosis. Therefore it is essential to improve our knowledge of the cellular and molecular mechanisms of the progress of renal fibrosis in order to achieve a reversion/elimination of renal fibrosis.
\end{abstract}

Chronic kidney disease (CKD) represents a serious hazard to human health, and has a high prevalence. In developed countries, it is estimated that more than $10 \%$ of adults present some degree of CKD (1). Despite a varied initial evolution, which is related to the diversity of its aetiologies - namely

This article is freely accessible online.

Correspondence to: Paula A. Oliveira, Department of Veterinary Sciences, CITAB, University of Trás-os-Montes and Alto Douro, 5001-801 Vila Real, Portugal. E-mail: pamo@utad.pt

Key Words: Rats, mice, disease, kidneys, renal function, review. genetics, autoimmune-related infections, environmental factors, diet, and drugs - progressive renal disease frequently results in renal fibrosis and finally in renal failure. The mechanisms implicated in renal fibrosis are still poorly understood, and existing therapies are ineffective or only slightly successful, hence it is essential to understand the pathophysiological mechanisms underlying the usual development of CKD, and to discover and better understand new strategies for treating this disease. In order to study the biopathology of this disease and to evaluate new treatments, animal models are required. The perfect animal model for renal disease research should have human-like renal anatomy, haemodynamics and physiology, as well as enabling the determination of relevant renal, biochemical and haemodynamic parameters. In all probability, no species can consistently meet all these requirements, and the experimental plan and other constraints often determine the choice of animal models for particular research applications. With this in mind, this review aims to describe and analyze animal models of renal fibrosis and suggest new areas of research.

\section{Renal Fibrosis: Aetiology and Pathophysiology}

Diabetes and hypertension are currently the two principal causes of CKD (2), among other causes such as infectious glomerulonephritis, renal vasculitis, ureteral obstruction, genetic alterations, autoimmune diseases (1) and drugs (3, 4). In general, diabetes causes glomerular hypertension by reducing the afferent arteriolar resistance while stimulating the efferent arterioles (2). Thus, elevated glomerular capillary pressure is one of the major factors in progressive renal sclerosis (5). Diabetes and hypertension gradually lead to glomerular expansion, which causes endothelial dysfunction and haemodynamic changes: loss of the glomerular basement membrane electric charge and its thickening, a decreased number of podocytes, foot-process effacement and mesangial distension have been shown to 
underlie the initial glomerular injury, which probably leads to glomerulosclerosis. (1). The reaction of renal tissue to damage resembles the common wound-healing response that occurs in other tissues. However, the repair and recovery of tissue function does not always happen, so why do some wounds heal and others progress to fibrosis? The answer is difficult because there are a variety of factors that influence the response to injury (6). The glomerulus is a structure with multiple interactions of endothelial, mesangial and epithelial cells that form the filtering capillary loops (5). Progression of CKD is evidenced by the loss of renal cells and their replacement by extracellular matrix (ECM) $(5,7)$ in glomeruli and interstitium. Chronic glomerulonephritis, tubulointerstitial disease, hypertension, or diabetic nephropathy (8), occurring independently of the associated disease, arise as a consequence of increased synthesis/reduced degradation of $\operatorname{ECM}(5,7,9)$. The pathogenesis of glomerulosclerosis has strong similarities to the pathogenesis of tubulointerstitial fibrosis. In general, glomerulosclerosis and tubulointerstitial fibrosis are the result of an imbalance between the excessive synthesis and decreased breakdown of the ECM, which may result from a normal wound-healing response becoming deregulated, with an uncontrolled inflammatory response and myofibroblast proliferation (10). In this sense matrix metalloproteinases and their tissue inhibitors are determinants of ECM accumulation (9). In addition, Hewitson suggests that fibrosis may also result from a collapse of the renal parenchyma (6). The end-stage of renal disease is manifested by the presence of glomerulosclerosis, vascular sclerosis and tubulointerstitial fibrosis. Indeed, glomerulosclerosis is initially attributable to the disproportionate production of ground substance proteins by mesangial cells, associated with a reduction in the extracellular proteolytic activity generated by these cells (2). In this sense, the excessive glomerular production of transforming growth factor (TGF)$\beta$, the key cytokine in the development of glomerulosclerosis and tubulointerstitial fibrosis (11), stimulates mesangial cells $(2,12)$, and is probably the most potent inducer of epithelialmesenchymal transition (13). Activation of TGF $\beta$ results in a self-maintaining cycle of matrix deposition, through an increase in protein synthesis and a decrease in matrix protein degradation, resulting in persistent tissue injury $(11,14)$. The diminution of this cytokine bioactivity reduces ECM deposition and the development of fibrosis in experimental renal injury (11). On the other hand, an increase in oxidative stress has been associated with increased mesangial expression of TGF $\beta$ (2) and also stimulation by angiotensin II (Ang II) (15). Endothelial and mesangial oxidant stress related to diabetes and systemic hypertension may also interfere with the production of glomerular nitric oxide, possibly reducing the activity of nitric oxide and thus impairing its protective effect in the process of glomerulosclerosis (2). However, there are additional nonhaemodynamic factors, such as growth factors, protooncogenes, infiltrating macrophages, proteinuria, reactive oxygen species, hyperlipidaemia and vasoactive substances, such as Ang II and endothelin, that contribute to renal sclerosis. Nevertheless the activity of these factors probably depends on the type of initial damage, the age of the individual when the injury occurs, and complex genetic factors, all of which influence the process of sclerosis (5). Thus, renal fibrosis can also be considered as tubulointerstitial fibrosis, since this process features tubular destruction. Curiously glomerulosclerosis, despite being a disease with its own entity, causes tubulointerstitial fibrosis by inducing tubular destruction. Although it is assumed that tubulointerstitial fibrosis accelerates the degeneration of injured nephrons and these may also interfere with neighbouring healthy tubules, contributing to the progression of kidney fibrosis (16). Existing knowledge about the progression of renal fibrosis is extraordinarily complex and therefore it is difficult to prevent or even eliminate renal fibrosis. Nevertheless, as referred to by Fogo, this is theoretically possible (5). There is great interest in uncovering the processes and underlying factors that lead to renal fibrosis in order to prevent or reverse renal fibrosis. (17). However, it is uncertain whether the elimination of fibrosis will in itself be sufficient to improve renal function, while beyond this, it is also necessary to eliminate inflammation and fibrogenesis, followed by the regeneration and reconstruction of tissue (6). Kaissling and colleagues suggest that renal fibrosis may have a curative component or, on the other hand, that fibrotic tissue supports the survival of healthy and partially injured nephrons (16).

\section{Impact of Renal Fibrosis on Human Health}

In recent years, the incidence of CKD has grown in a frightening way. If this tendency persists, even wealthier countries will not be able to come up with sufficient resources to adequately treat this disease (18). Although it is recognized that the kidney has a capacity for regeneration after acute injury, regeneration and recovery, following chronic injury this is much more difficult. Thus this process is often irreversible, leading to end-stage renal collapse, a situation that requires dialysis or renal transplantation (6). In general, between $30-40 \%$ of individuals develop considerable kidney failure 10-15 years after the diagnosis of progressive nephropathy (19). It is estimated that currently between 1 and 2 million people are being treated with renal replacement therapy (19-21), which primarily involves kidney transplantation and haemodialysis. Over $90 \%$ of these patients live in developed countries, although the availability of renal replacement therapy in developing countries is limited, and insignificant or non-existent in underdeveloped 
countries. Given the fact that renal replacement therapy represents a high cost burden on national health budgets, this prevents all patients from being given access to this type of treatment (19). The latest estimate, based on results from the US Census Bureau predicted that by the year 2015 the number of cases on renal replacement therapy will be $>595,000$ (22). The public cost necessary to care for these patients will be considerably greater than it was in 2010 (\$28 billion per year), regardless of the exact number of cases (18, 22 ). If these numbers were to be estimated for the entire world's population, the total number of individuals with CKD could be estimated to be in the hundreds of millions.

Humans and animals develop glomerulosclerosis, interstitial fibrosis, tubular atrophy and reduction in glomerular filtration rate with increasing age (23). In humans with CKD, the development of glomerulosclerosis is evidenced by the progressive involvement of segments within individual glomeruli, a decrease in the total number of glomeruli and by the simplification and elimination of tubular structures (15). The presence of fibrosis in CKD is strongly related to the future manifestation of renal failure and has thus been related with poor long-term prognosis (24). Renal fibrosis is one of the consequences of kidney injury and is associated with renal dysfunction that may culminate in renal collapse $(25,26)$. Renal fibrosis, particularly associated with glomerulosclerosis and renal interstitial fibrosis $(5,10,27,28)$ that is characterised by tubular atrophy, tubular dilatation, increased fibrogenesis (29) and deposition of collagen and ECM (15), can progress in humans as a consequence of chronic infection, obstruction of the ureters, hypertension, diabetic nephropathy and chronic exposure to heavy metals (25).

\section{Principal Molecules, Cells and Other Factors Involved in the Pathogenesis of Renal Fibrosis}

In the following section we describe the main molecules and cells that are associated with progression of renal fibrosis and their activity in the biological process of renal fibrotic development, such as Ang II, TGF $\beta$, connective tissue growth factor (CTGF), plasminogen activator inhibitor-1 (PAI1), nuclear factor-kB (NFKB), fibroblasts, and proteins (Figure 1).

\section{Angiotensin II}

All the components of the renin-angiotensin system (including enzymes and receptors) are present in the kidney, and renal Ang II is approximately one thousand-fold greater than the circulating concentrations of Ang II (15). Therefore, increased levels of Ang II modulate fibrosis by the direct effects on the matrix and by up-regulating the expression of other factors, such as $\operatorname{TGF} \beta(5,14)$, platelet-derived growth factor (5) (which plays a crucial role in the development of mesangial proliferation) (10), CTGF (30), nicotinamide adenine dinucleotide phosphate (NADPH) oxidase activity (2), PAI1 (19), tumour necrosis factor- $\alpha$, osteopontin, vascular cell adhesion molecule-1, and $\mathrm{NFKB}$ (NFKB activation is also strongly associated with an increase in renal fibrosis) $(15,31)$. Ang II also induces oxidative stress. It is believed that most of these negative effects of Ang II are mediated by the Ang II type-1 (AT1) receptor. These factors and the vasoactive compounds involved in the progression of renal fibrosis have been studied in various models of renal diseases (15).

Cell growth after injury is frequently followed by increased apoptosis. Apoptosis may be induced by Ang II and this effect is mediated by the Ang II type-2 (AT2) receptor, showing a possible role for AT2 receptors in the regression of renal fibrosis. This is demonstrated by the activity of the AT2 receptor in the reduction of vascular lesions after damage. In addition, regression of glomerulosclerosis can be achieved by angiotensin inhibition in animal studies, however, this can become more effective when used in combination with an aldosterone antagonism (5) or with TGF $\beta$ blockers (20). Renin and aldosterone appear to have fibrogenic effects regardless of Ang II activity, however, it is not known if aldosterone and renin up-regulate TGF $\beta$ expression (32), or whether they may be intimately connected with TGF $\beta$ production and accumulation of fibrotic matrix.

\section{Transforming Growth Factor $\beta$}

The accumulation of ECM proteins, which is associated with the progression of glomerulosclerosis/renal interstitial fibrosis and tissue inflammation, seems to be related mainly with the activity of Ang II and TGF $\beta(20,32,33)$. TGF $\beta$ is secreted in an inactive (latent) form that requires processing before it can exert its effect and latent TGF $\beta$ is stored on the surface of cells and the ECM, where it is transformed to active TGF $\beta$ (15). Along these lines, Kagami et al. showed that Ang II induces ECM synthesis and that these effects are mediated directly by Ang II induction of the active form of TGF $\beta$ (12), indicating that TGF $\beta$ contributes to renal fibrosis $(2,12,20,31,32)$. In mammals there are three TGF $\beta$ isoforms, however, the form most associated with renal fibrosis is TGF $\beta 1$ (34). TGF $\beta 1$ is extensively expressed in all cells of the kidney, particularly in glomeruli, where the levels are several times those in the kidney as a whole (20), or expressed by macrophages that invade the kidney (15). TGF $\beta$ plays a pivotal role in renal fibrogenesis $(7,11,20,35)$, indeed the kidney is particularly susceptible to the overexpression of TGF $\beta$ (32).

TGF $\beta$ simultaneously regulates cellular proliferation, differentiation and migration, modulation of the immune response (7), fibroblast proliferation (15), stimulation of oxidative stress (increasing NADPH oxidase activity in 


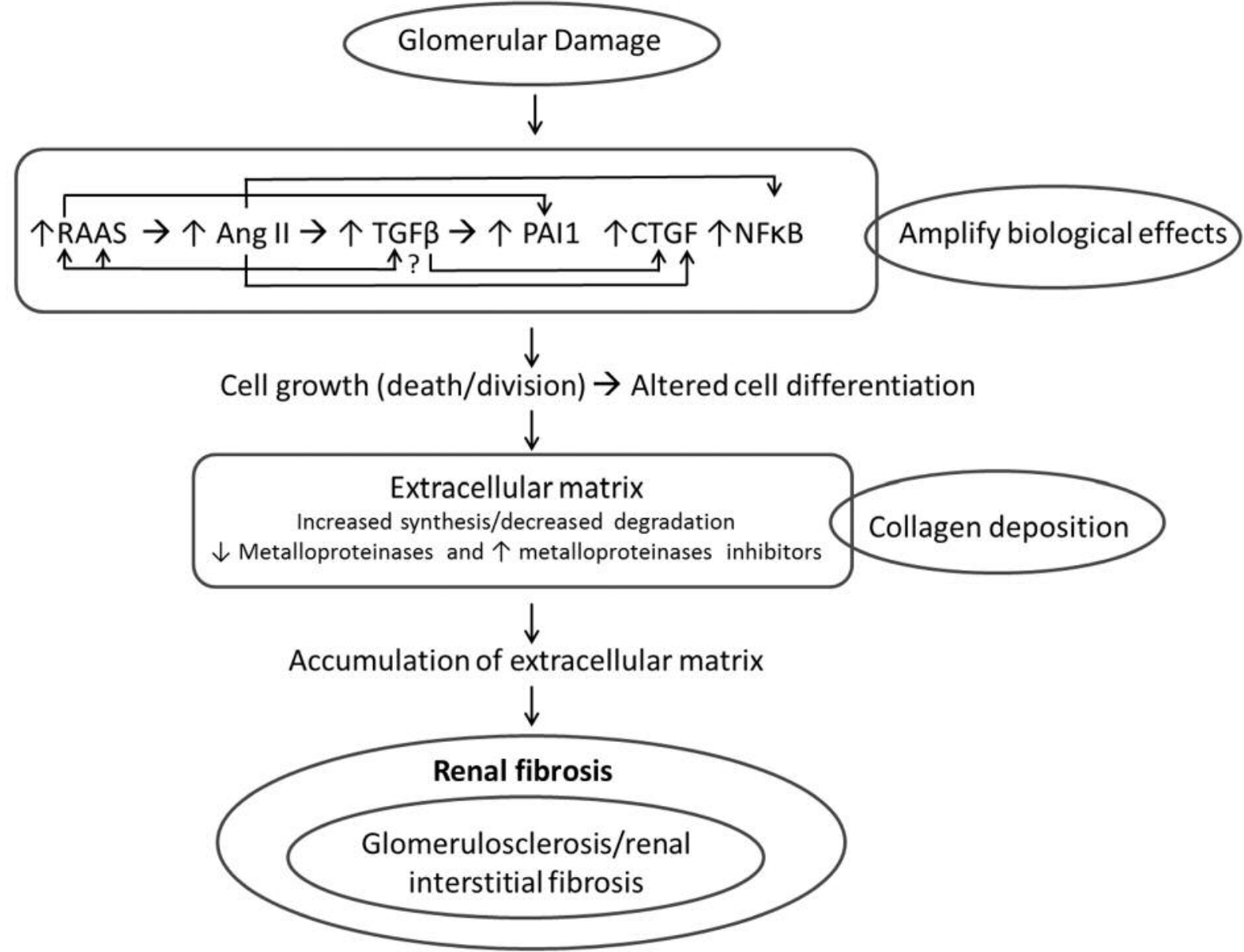

Figure 1. Glomerular injury can be associated with different causes, leading to endothelial dysfunction and haemodynamic changes. Activation and amplification of many biological effects particularly with production of angiotensin II (Ang II) that up-regulates the expression of other factors, such as transforming growth factor- $\beta(T G F \beta)$, connective tissue growth factor (CTGF), plasminogen activator inhibitor-1 (PAI1) and nuclear factor$\mathrm{\kappa} B(N F \mathrm{~K} B)$, leading to initial recruitment of neutrophils which is substituted by macrophages and T-lymphocytes, triggering an immune response, causing interstitial nephritis. Tubular cells respond to this inflammatory process by forming a lesion of the basal membrane and by epithelialmesenchymal transition transformed into interstitial fibroblasts. The formed fibroblasts produce collagen, and result in an imbalance between excessive synthesis and decreased breakdown of the extracellular matrix, which in turn damages the blood vessels and the kidney tubules, with the possibility of forming of a cellular scar and consequently renal fibrosis. RAAS: Renin-angiotensin-aldosterone system.

mesangial cells) (2), synthesis of ECM, inhibits the activities of proteases that degrade the matrix, and increases the expression of cell-surface integrins that interact with matrix components, causing an extremely high deposition of ECM (32). In this sense, TGF $\beta$ induces ECM by stimulating the production of matrix proteins, reducing the production of ECM-degrading proteinases and up-regulating the production of proteinase inhibitors, and induces glomerular mesangial and epithelial cells (in vitro) to produce collagens, fibronectin, proteoglycans (20), laminin (2) and endothelin (15). Another important factor is the ability of TGF $\beta$ to stimulate its own synthesis and activation, resulting in a selfsustaining autocrine loop (2). On the other hand, TGF $\beta$ also contributes to ECM through the up-regulation of PAI1 (5, 32) and increased renin release (32) in isolated glomeruli, reducing the activity of matrix-degrading metalloproteinase (20). This alteration to matrix degradation is also associated with a raised expression of CTGF (2).

\section{Connective Tissue Growth Factor}

Yang et al. demonstrated that Ang II directly induces CTGF, as well as collagen I. Ang II was found to induce CTGF expression through a TGF $\beta 1$-independent SMAD signalling pathway via the AT1-extracellular signal-regulated kinase/p38 mitogen-activated protein kinase signaling 
pathway to induce renal fibrosis in tubular epithelial cells (30). On the other hand, induction of CTGF by TGF $\beta 1$ is markedly inhibited by SMAD7 overexpression $(30,36)$. In another study, in vivo results showed that Ang II directly activates the SMAD pathway in the vessel wall and regulates numerous SMAD-dependent proteins implicated in vascular fibrosis, by a direct TGF $\beta$ independent mechanism (37). This demonstrates the crucial function of SMAD signalling in the Ang II-mediated fibrotic process (30). The RAS/MEK/ ERK1/2 signaling pathway is also required for the stimulation of CTGF by TGF $\beta 1$ in human proximal tubular epithelial cells, and among the RAS isoforms that are expressed in human kidney cells, NRAS but not KRAS or HRAS were required for the induction of CTGF by TGF $\beta 1$ (36). CTGF also appears to be correlated with the degree of tubulointerstitial fibrosis in experimental and human renal fibrosis studies (11). Indeed, CTGF is most abundant in the kidney compared to other tissues, and is an important mediator of renal fibrosis. In a way, there is real potential for CTGF to become a therapeutic target for the treatment of renal fibrosis. CTGF and TGF $\beta$ act jointly to promote chronic fibrosis $(11,36)$.

\section{Plasminogen Activator Inhibitor-1}

PAI1 is another mediator that is associated with increased renal fibrosis (19), by stimulation of fibronectin and type III collagen (15). Ang II may also promote PAI1 directly, both in vitro and in vivo (5), which may lead to an accumulation of ECM by reducing the activities of plasmin in eliminating the matrix and stimulating collagenases (32). This shows that the Ang II blockade is extremely important in combatting the evolution of renal fibrosis.

\section{Nuclear Factor-кB}

NFKB has a role in the transcriptional regulation of a quantity of genes in different tissues, namely the renal cells (38). NFKB is located in the cell cytoplasm in an inactive form, linked to an inhibitor, the activated form of NFKB is a homodimer or heterodimer, structured by two proteins that are part of the NFKB family. In this sense, transcription factors of the NFKB family can stimulate cells, directly or indirectly, triggering tissue fibrosis (15). Ang II can be activated by NFkB through both the AT1 and AT2 receptors. The NFKB family of transcription factors have several potential associations, it is probable that different $\mathrm{NFKB}$ isotypes are stimulated by Ang II at different phases in the progression of renal disease (31). The tissue enzyme transglutaminase (protein expressed by kidney tubular epithelial cells) is an activator of latent TGF $\beta 1$ and the activating of transglutaminase is regulated by $\mathrm{NFKB}$, consequently this fact appears to be associated with an increase of renal fibrosis. The increased expression of asmooth muscle actin promotes the kidney fibroblasts to achieve a myofibroblastic phenotype (15). It appears that $\mathrm{NFKB}$ may be associated with an increase in $\alpha$-smooth muscle actin expression during liver fibrosis (39). As mentioned above, Ang II can promote $\mathrm{NFKB}$ activation, activating tumour necrosis factor- $\alpha$ synthesis; this in turn can additionally activate $\mathrm{NFKB}$. A $40 \%$ reduction in tumour necrosis factor- $\alpha$ mRNA expression was verified with angiotensin-converting enzyme inhibition in rats with kidney disease, perhaps due to the weakening of a group of NFKB homodimers or heterodimers (31). Therefore, the progression of renal fibrosis might be treated or improved by inhibition of NFKB $(15,38,40)$.

\section{Fibroblasts}

The progression of renal fibrosis is a complex process, since many factors and cells are involved, especially mesenchymal cells (6). Epithelial-mesenchymal transition, a process by which differentiated epithelial cells give rise to the matrixproducing fibroblasts and myofibroblasts, is increasingly documented as an integral part of tissue fibrogenesis after renal injury $(13,35,41)$. In this sense, tubular epithelial cells are also important in the pathogenesis of tubulointerstitial fibrosis (29). Thus, epithelial-mesenchymal transition, such as occurs in common glomerular diseases, could be a primary pathway leading to podocyte dysfunction, proteinuria, and glomerulosclerosis (13). Fibroblasts are mesenchymal cells involved in the progression of renal disease. Fibroblasts of the renal interstitium can play a contractile myofibroblastic phenotype and has the ability to originate fibrillar collagen-rich ECM, leading to impaired renal function. The number of fibroblasts increase during renal disease and can be activated by many cytokines, especially TGF $\beta 1$ or differentiate into myofibroblasts (34).

\section{Proteins}

Another strategy for preventing, or at least slowing, the onset of glomerulosclerosis is a low-protein diet because a high protein intake increases the glomerular filtration rate by reducing afferent arteriolar resistance and consequently increasing glomerular capillary pressure (2). Elevated levels of urinary proteins, which correspond to excess protein passage through the glomerulus, are related to a quicker progression of renal disease (20). Thus, proteinuria is also an important factor of progression in animal and human renal diseases. One of the factors that causes glomerular and tubular changes includes enhanced glomerular capillary pressure by altering glomerular permeability to proteins, allowing proteins to pass across the glomerular filter and reach the lumen of the proximal tubule. Another factor of 
tubular reabsorption of filtered proteins that contributes to interstitial damage is by activating intracellular events, leading to up-regulation of the genes encoding vasoactive and inflammatory mediators (20).

\section{Animal Models of Renal Fibrosis}

Experimental models are widely used to study the mechanisms involved in the progression of renal diseases to renal fibrosis $(5,7)$. Research on natural aging of the rat kidneys indicate that both gender and genetic background influence the rate, as well as the level, of impairment and scarring from renal disease. Normally, age-related renal scarring begins earlier and becomes more severe in male rats than in females, and Sprague-Dawley rats are less resistant than other rat strains. Research into aging in mice suggests that strain and gender also influence the progression of renal disease (23). It is important to emphasize that these changes are clearly different from the compensatory changes that occur after reduction of renal mass (42). To study renal fibrosis, induced models (surgical and chemical), spontaneous models, genetic models and in vitro models (29, 43-48) can be used.

\section{Chemical Models of Renal Fibrosis}

There are several chemical models for studying renal fibrosis, each of which has advantages and disadvantages We describe each of them below in turn, while in Table I, the practical application of each of these models in the therapeutic evaluation of different drugs is presented.

Mercuric chloride $\left(\mathrm{HgCl}_{2}\right)$. $\mathrm{HgCl}_{2}$ per os in Sprague-Dawley rats once a day for 9 weeks led to renal interstitial fibrosis with an increased amount of collagen. The effect of $\mathrm{HgCl}_{2}$ is characterized by the activation of renal fibroblasts, the overproduction and deposition of ECM, increased renal lipid peroxidation (49), elevated $\mathrm{NFKB}$ activity (50), renal necrosis and tubular dysfunction in rats (51).

Vanadate. Vanadate injected subcutaneously in SpragueDawley rats aged 11 weeks at a dosage of $0.9 \mathrm{mg} / \mathrm{kg}$ per day for 16 days caused inflammation and renal fibrosis. The pathological and biochemical changes were more severe in the kidney tissue. After 2 days, degenerative and necrotic changes of the tubular and glomerular epithelium were identified. After 12 days, cellular proliferation in both the cortex and medulla was significantly greater and there was verifiable renal fibrosis: glomerular tuft, preglomeruli, pretubules and interstitium (cortex and medulla). After 25 days, collagen deposition reached the highest degree in all areas of the kidney. Vanadium-produced fibrosis in tissues is dose-dependent (52).
Adriamycin. Adriamycin is an antineoplastic drug that induces side-effects such as lipid peroxidation in glomerular epithelial cells. Adriamycin induced rat nephropathy with massive proteinuria, tubular basement membrane lesions, probably causing an inflammatory response and interstitial fibrosis (4). Adriamycin administration at a dosage of $10 \mathrm{mg} / \mathrm{kg}$ for each mouse by means of a single intravenous tail-vein injection causes proteinuria, glomerular and podocyte injury, followed by tubular atrophy and finally renal fibrosis (53-55). In a study with BALB/c mice, proteinuria was verified on day 5 and at higher levels on day 7; after weeks 1 and 2 glomerular and tubular lesions were observed, and by week 4 these changes were more evident. After week 6, kidney inflammation was observed, as well as severe glomerulosclerosis and interstitial fibrosis (53). The adriamycin-induced nephropathy model mimics human disease of focal segmental glomerulosclerosis (54) and is also often used to model nephrotic syndrome (23). This model is also excellent for investigating glomerulosclerosis in humans (23).

Uranyl nitrate. Uranyl nitrate administrated by intraperitoneal route $(0.3$ or $0.5 \mathrm{mg} / 100 \mathrm{~g})$ causes renal fibrotic changes in rats. Uranyl nitrate administration induced mild to moderate patchy interstitial fibrosis after 4 weeks. After 20 weeks, fibrotic areas containing atrophic tubules with a thickened tubular basement membrane and mild lymphocytic infiltration were identified. Uranyl nitrate administration induced renal fibrosis in a dose-dependent manner (29). In another study, uranyl nitrate administration of $10 \mathrm{mg} / \mathrm{kg}$ in rats for a period of 2 months appeared to cause chronic injuries, as demonstrated by increased interstitial fibrosis, atrophic proximal tubules and mononuclear cell infiltrates. These authors suggest that the administration of uranyl nitrate in rats induced renal failure with a slow recovery phase and longterm pathological lesions (56). Uranyl nitrate appears to be an optimal model of interstitial fibrosis and is useful for investigating molecular mediators of kidney damage (29).

Folic acid. Folic acid administered via the intraperitoneal route $(240 \mathrm{mg} / \mathrm{kg})$ in mice induced the rapid appearance of folic acid crystals in tubules, followed by severe nephrotoxicity, between 1-14 days of the administration period. By 28-42 days, these animals developed patchy interstitial fibrosis. Severe damage induced by folic acid is associated with a direct toxic effect on tubular epithelial cells and by crystal obstruction of individual tubules. However, the co-administration of $\mathrm{NaHCO}_{3}$ and folic acid provokes urine alkalinisation, reducing crystal formation $(23,57)$. The folic acid interstitial fibrosis model, compared to the unilateral ureteral obstruction (UUO) model, has the advantage of enabling assessment of renal function as a measure of CKD. On the other hand, this model has the limitation of being somewhat variable and the possibility exists that fibrosis in 
some mice will regress spontaneously after 42 days. This model is good for studying interstitial fibrosis (23).

Streptozotocin-diabetic rats. Streptozotocin administration $(65 \mathrm{mg} / \mathrm{kg}$ i.v.) in rats increases blood glucose concentration. After 4 or 8 weeks of streptozotocin administration, animals showed collagen deposition in the kidneys, elevated renal plasma fibronectin concentrations (58) and elevated plasma levels of TGF $\beta$, up to four times the normal levels (14). This model can be considered as a renal fibrosis model because sometimes, after the onset of diabetes, renal fibrosis may occur (58).

Cyclosporine A. Cyclosporine A, a primary calcineurin inhibitor, is used clinically as an immunosuppressive agent to enhance the efficacy of organ transplantation. However, prolonged use of cyclosporine A can induce renal fibrosis. Thus, its clinical use is in part limited by its nephrotoxicity effect $(3,59)$. The cyclosporine A model is good for studying interstitial fibrosis (23). However, this model has some disadvantages: high cost, liver toxicity, extensive trial period (4) and the concentrations of cyclosporine A that are commonly used in animal studies are much higher than those used in clinical practice (60).

\section{Physical Models - Radiation Nephropathy}

Radiation nephropathy can be induced by a local dose $(10 \mathrm{~Gy})$, with shielding of the gastrointestinal tract and without systemic toxicities. Radiation nephropathy leads to the development of endothelial injury and chronic progressive secondary sclerosis with proportional tubulointerstitial fibrosis (23). In Sprague-Dawley rats, radiation $(12 \mathrm{~Gy})$ induces an initial decline in glomerular filtration rate and at a later stage, the damage involves complex interactions between glomerular, tubular and interstitial cells, which may culminate in interstitial fibrosis with mild interstitial inflammation. In addition to the likely involvement of TGF $\beta$ and PAI1, Ang II is certainly the principal mediator of this process. The results of this study showed that sulodexide $(15 \mathrm{mg} / \mathrm{kg} /$ day by subcutaneous injection, 6 days/week for 4, 8 and 12 weeks) is effective in reducing the early, but not late, indicators of radiation nephropathy and has no influence on renal damage, despite sulodexide considerably diminishing TGF $\beta$ activation (61).

\section{Surgical Models to Induce Renal Fibrosis}

There are three main surgical models to study renal fibrosis, each of which has its advantages and disadvantages. We describe each of them below, and Table II shows the practical application of each of these models in the therapeutic evaluation of different drugs.
5/6 Renal mass reduction. Over the last 50 years, models using animals that have undergone surgical renal reduction have been used to study progressive renal disorders $(17,62)$. The remnant kidney model of progressive renal disease has been used in different rat and mouse strains to study the pathogenesis of glomerulosclerosis. The 5/6 renal mass reduction model in rats is frequently studied to evaluate alterations in the progression of chronic kidney failure, namely renal fibrosis $(5,7,63)$. A study conducted by Hostetter and colleagues highlighted the action of glomerular hyperfiltration in the development of lesions in remnant glomeruli in rats (64). However, Ma and Fogo, in a study that used the remnant kidney model, recorded small glomerular changes in C57BL/6 mice. On the other hand, in $129 / \mathrm{Sv}$ and Swiss-Webster strains, mice were observed to have significant glomerular sclerosis, so to some extent these results demonstrate the effect of genetic background on renal response to renal reduction (65). Sensitivity to the development of glomerulosclerosis and hypertension in 129/Sv and C57BL/6 strains may be predisposed by renin gene polymorphisms. Mice with two renin genes have 10times greater renin activity in their plasma compared with mice with one renin gene. Because of this increased renin activity in $129 / \mathrm{Sv}$ mice, they exhibit a greater predisposition for developing hypertension and glomerulosclerosis (66). Although research studies focus on the various processes of kidney function, clinical studies have also established that the development of renal failure correlates more with renal interstitial fibrosis than with glomerular injury (17).

In the 5/6 renal mass reduction animal model, a renal mass reduction of $>85 \%$ is required to simulate the decrease in the number of nephrons that occurs with CKD, which makes this model an excellent model for studying the mechanisms involved in compensatory adaptations to nephron loss. The 5/6 renal mass reduction model is achieved by unilateral nephrectomy, followed by the removal of two-thirds of the remaining kidney $(67,68)$. For the study of renal disease, this can be performed in one of two ways: a) unilateral nephrectomy plus polectomy of the remnant kidney, resulting in approximately 5/6 renal mass reduction; and b) unilateral nephrectomy plus complete ligation of two branches of the contralateral renal artery, resulting in infarction of approximately $2 / 3$ of the remnant kidney, which produces an overall $5 / 6$ renal mass nullification (1). In the $5 / 6$ renal mass reduction model, the remaining nephrons increase their filtration rate (64) to preserve the excretory function; renal dysfunction occurs when the remaining nephrons are unable to perform this excretory function (1). Over time, these animals develop a syndrome of systemic and glomerular hypertension (68), proteinuria (64) and matrix expansion (5), and by 12 weeks present progressive glomerulosclerosis and tubulointerstitial fibrosis in the originally healthy remnant nephrons $(23,62$, 
in vivo $31: 1-22$ (2017)

Table I. Chemical models used for renal fibrosis study - drugs evaluated and their efficacy.

\begin{tabular}{|c|c|c|c|c|}
\hline $\begin{array}{l}\text { Drug-induced } \\
\text { models }\end{array}$ & $\begin{array}{l}\text { Strain/gender/ } \\
\text { age, weight }\end{array}$ & Protocol & $\begin{array}{c}\text { Drugs and } \\
\text { compounds evaluated }\end{array}$ & $\begin{array}{l}\text { Results and therapeutic } \\
\text { effects (reference) }\end{array}$ \\
\hline \multirow[t]{3}{*}{$\mathrm{HgCl}_{2}$} & $\begin{array}{c}\text { Sprague-Dawley/ } \\
\delta / 120 \pm 10 \mathrm{~g}\end{array}$ & $\begin{array}{l}8 \mathrm{mg} \mathrm{HgCl} / \mathrm{kg} / \text { day p.o. } \\
\text { for } 9 \text { weeks to induce } \\
\text { renal interstitial fibrosis }\end{array}$ & $\begin{array}{c}\text { Fuzheng Huayu formula and } \\
\text { vitamin } \mathrm{E} \text { by oral gavage }(4.0 \mathrm{~g} \\
\text { crude drug/kg/day and } 100 \mathrm{mg} / \mathrm{kg} / \\
\text { day, respectively) for } 9 \text { weeks }\end{array}$ & $\begin{array}{l}\text { Fuzheng Huayu formula and } \\
\text { Vitamin E demonstrated an } \\
\text { inhibitory effect on renal } \\
\text { fibrosis induced by } \mathrm{HgCl}_{2}(49)\end{array}$ \\
\hline & $\begin{array}{c}\text { Sprague-Dawley/ } \widehat{\jmath} / \\
120 \pm 10 \mathrm{~g}\end{array}$ & $\begin{array}{c}8 \mathrm{mg} \mathrm{HgCl} \mathrm{H}_{2} / \mathrm{kg} / \text { day } p . o . \text { for } \\
9 \text { weeks to induce renal } \\
\text { interstitial fibrosis }\end{array}$ & $\begin{array}{c}100 \mathrm{mg} \text { Vitamin } \mathrm{E} / \mathrm{kg} / \mathrm{day} \\
\text { by gastric gavage for } 9 \text { weeks }\end{array}$ & $\begin{array}{l}\text { Vitamin } \mathrm{E} \text { shown to inhibit } \\
\text { renal interstitial fibrosis } \\
\text { induced by } \mathrm{HgCl}_{2}(50)\end{array}$ \\
\hline & $\begin{array}{l}\text { Wistar/ } / \delta / 8 \text { weeks } \\
\text { and } 20 \text { months }\end{array}$ & $\begin{array}{l}2.5 \mu \mathrm{mol} \mathrm{HgCl}_{2} / \mathrm{kg} / 2 \mathrm{ml} \\
\text { i.v. for } 4 \text { weeks to induce } \\
\text { renal interstitial fibrosis }\end{array}$ & - & $\begin{array}{l}\text { Renal function is significantly } \\
\text { compromised in aged rats, resulting } \\
\text { in chronic renal insufficiency, and } \\
\text { the accumulation of } \mathrm{HgCl}_{2} \text { in aging } \\
\text { rats is significantly altered } \\
\text { compared to that of young rats (51) }\end{array}$ \\
\hline \multirow[t]{2}{*}{ Vanadate } & $\begin{array}{l}\text { Sprague-Dawley/ } \\
\qquad / 9 \text { weeks }\end{array}$ & $\begin{array}{l}1 \mathrm{mg} \text { Vanadate } / \mathrm{kg} / \mathrm{day} \text { s.c. for } \\
12 \text { days to induce mild to moderate } \\
\text { kidney lesions and the same treatment } \\
\text { protocol for } 16 \text { days to induce } \\
\text { moderate to severe kidney lesions }\end{array}$ & $\begin{array}{c}500 \mathrm{mg} \text { Pirfenidone } / \mathrm{kg} / \text { day } \\
\text { by oral gavage for } \\
23,37 \text { and } 41 \text { days }\end{array}$ & $\begin{array}{l}\text { Pirfenidone treatment } \\
\text { decreases vanadate-induced } \\
\text { renal fibrosis }(25)\end{array}$ \\
\hline & $\begin{array}{l}\text { Sprague-Dawley/ } \\
\hat{\delta} / 11 \text { weeks }\end{array}$ & $\begin{array}{c}0.9 \mathrm{mg} \text { Vanadate } / \mathrm{kg} / \mathrm{day} \text { s.c. for } \\
16 \text { days to evaluate the effects } \\
\text { of vanadate on renal tissue }\end{array}$ & - & $\begin{array}{l}\text { Vanadate treatment induced } \\
\text { renal fibrosis in a } \\
\text { dose-dependent manner (52) }\end{array}$ \\
\hline \multirow[t]{3}{*}{ Adriamycin } & $\begin{array}{l}\mathrm{BALB} / \mathrm{c} / ठ^{\Uparrow} / \\
6 \text { to } 8 \text { weeks }\end{array}$ & $\begin{array}{l}\text { A single administration of } 10 \mathrm{mg} \\
\text { adriamycin } / \mathrm{kg} \text { i.v., urine, blood } \\
\text { and kidney samples were collected } \\
\text { on the day of sacrifice }(1,3, \text { or } \\
5 \text { weeks after adriamycin injection) }\end{array}$ & $\begin{array}{l}\text { Atrasentan by i.p., two different } \\
\text { protocols: } 1 \text { : prevention protocol } \\
\text { ( } 5 \mathrm{mg} / \mathrm{kg} \text {; daily starting the day } \\
\text { prior to adriamycin injection); } \\
2: \text { therapeutic protocol ( } 7 \text { and } \\
20 \mathrm{mg} / \mathrm{kg} \text { ) three times weekly }\end{array}$ & $\begin{array}{l}\text { Atrasentan was ineffective in } \\
\text { improving renal injury } \\
\text { associated with adriamycin- } \\
\text { induced nephropathy (54) }\end{array}$ \\
\hline & $\begin{array}{l}\mathrm{BALB} / \mathrm{c} / \jmath^{\Uparrow} \\
8 \text { to } 10 \text { weeks }\end{array}$ & $\begin{array}{l}\text { A single administration of } 10 \mathrm{mg} \\
\text { adriamycin } / \mathrm{kg} \text { i.v., urine, blood and } \\
\text { kidney samples were collected } \\
(0,7,14 \text { and } 21 \text { days after } \\
\text { adriamycin injection })\end{array}$ & $\begin{array}{l}\text { Mas receptor agonist-AVE0991 } \\
\text { and Losartan ( } 3 \mathrm{mg} / \mathrm{kg} \text { p.o. and } \\
10 \mathrm{mg} / \mathrm{kg} \text { p.o., respectively) } \\
\text { from day } 7 \text { to day } 14 \text { after } \\
\text { adriamycin injection }\end{array}$ & $\begin{array}{l}\text { AVE0991 had a renoprotective } \\
\text { effect on adriamycin-induced } \\
\text { nephropathy, these effects were } \\
\text { similar to those of losartan. } \\
\text { AVE0991 and losartan reduced } \\
\text { histological injury indices (55) }\end{array}$ \\
\hline & $\begin{array}{l}\mathrm{BALB} / \mathrm{c} / \delta / \\
8 \text { to } 10 \text { weeks }\end{array}$ & $\begin{array}{l}\text { A single administration of } 10 \text { to } \\
11 \mathrm{mg} \text { adriamycin } / \mathrm{kg} \text { i.v., urine, } \\
\text { blood and kidney samples were } \\
\text { collected }(1,2,4 \text { and } 6 \text { weeks } \\
\text { after adriamycin injection) }\end{array}$ & - & $\begin{array}{l}\text { The results showed that the } \\
\text { model of adriamycin-induced } \\
\text { nephropathy may be useful in the } \\
\text { study of the pathogenesis } \\
\text { of renal fibrosis in CKD (53) }\end{array}$ \\
\hline \multirow[t]{2}{*}{ Uranyl nitrate } & $\begin{array}{l}\text { Wistar/9/ } \\
150-170 \mathrm{~g}\end{array}$ & $\begin{array}{c}0.3 \text { or } 0.5 \mathrm{mg} \text { Uranyl nitrate/ } \\
100 \mathrm{~g} \text { by only one } i . p ., \text { diuresis } \\
\text { experiments were performed } 2,4, \\
8,10,20 \text { weeks after uranyl } \\
\text { nitrate administration }\end{array}$ & - & $\begin{array}{c}\text { After } 4 \text { weeks, } 0.5 \text { mg uranyl } \\
\text { nitrate administration caused a } \\
\text { mild to moderate patchy interstitial } \\
\text { fibrosis, after } 0.3 \text { mg uranyl nitrate } \\
\text { administration, renal fibrosis was } \\
\text { milder, after } 20 \text { weeks, } \\
\text { administration of uranyl nitrate had } \\
\text { induced renal fibrosis (29) }\end{array}$ \\
\hline & $\begin{array}{l}\text { Sprague-Dawley/ } \\
\lesssim / 250-300 \mathrm{~g}\end{array}$ & $\begin{array}{l}10 \mathrm{mg} \text { Uranyl nitrate/kg by a single } \\
\text { s.c., renal function studies and } \\
\text { morphological evaluation were } \\
\text { performed } 1,2,4 \text { and } 8 \text { weeks } \\
\text { after drug administration }\end{array}$ & - & $\begin{array}{l}\text { Administration of uranyl nitrate } \\
\text { appears to have caused chronic } \\
\text { lesions, since an increase in renal } \\
\text { fibrosis, particularly interstitial } \\
\text { fibrosis (56), was found }\end{array}$ \\
\hline Folic acid & $\mathrm{CD} 1 / ふ / 8$ weeks & $\begin{array}{c}240 \mathrm{mg} \text { Folic acid } / \mathrm{kg} \\
\text { by i.p., kidneys were } \\
\text { harvested at } 0.5,1,3 \\
7, \text { and } 14 \text { days for } \\
\text { histological evaluation }\end{array}$ & - & $\begin{array}{l}\text { After } 14 \text { days of folic acid } \\
\text { administration, cortical tubular } \\
\text { atrophy and interstitial } \\
\text { fibrosis (57) were observed }\end{array}$ \\
\hline
\end{tabular}


Table I. Continued

\begin{tabular}{|c|c|c|c|c|}
\hline $\begin{array}{l}\text { Drug-induced } \\
\text { models }\end{array}$ & $\begin{array}{l}\text { Strain/gender/ } \\
\text { age, weight }\end{array}$ & Protocol & $\begin{array}{c}\text { Drugs and } \\
\text { compounds evaluated }\end{array}$ & $\begin{array}{l}\text { Results and therapeutic } \\
\text { effects (reference) }\end{array}$ \\
\hline Streptozotocin & $\begin{array}{l}\text { Wistar/ぶ/ } \\
8-10 \text { weeks }\end{array}$ & $\begin{array}{l}\text { A single injection of } 65 \mathrm{mg} \\
\text { streptozotocin } / \mathrm{kg} \text { i.v., } \\
\text { experiments were performed } \\
4 \text { or } 8 \text { weeks after } \\
\text { streptozotocin treatment }\end{array}$ & $\begin{array}{l}\text { Pirfenidone and spironolactone } \\
\text { after } 4 \text { weeks, were given either } \\
200 \mathrm{mg} \text { pirfenidone/l drinking } \\
\text { water; or } 50 \mathrm{mg} \text { spironolactone/ } \\
\mathrm{kg} / \text { day s.c. for a further } 4 \text { weeks }\end{array}$ & $\begin{array}{l}\text { Pirfenidone and spironolactone } \\
\text { treatment reduced renal fibrosis } \\
\text { in the rat model of streptozotocin } \\
\text { treatment }(58)\end{array}$ \\
\hline \multirow[t]{6}{*}{ Cyclosporine A } & $\begin{array}{l}\text { Sprague-Dawley/ } \\
\delta / 180-230 \mathrm{~g}\end{array}$ & $\begin{array}{l}25 \text { mg Cyclosporine } \mathrm{A} / \mathrm{kg} / \mathrm{day} \\
\text { by oral gavage for } 21 \text { days } \\
\text { (but without salt diet), } \\
\text { measurements were performed } \\
\text { at the beginning and at } \\
\text { the end of treatment period }\end{array}$ & - & $\begin{array}{l}\text { Cyclosporine A administration } \\
\text { altered the proximal convoluted } \\
\text { tubules and glomeruli showed } \\
\text { significant damage to their } \\
\text { structural integrity (3) }\end{array}$ \\
\hline & $\begin{array}{l}\text { Sprague-Dawley/ } / \\
220-250 \mathrm{~g}\end{array}$ & $\begin{array}{l}20 \mathrm{mg} \text { Cyclosporine } \mathrm{A} / \mathrm{kg} / \mathrm{day} \\
\text { by gastric gavage for } 35 \text { days } \\
\text { (after } 1 \text { week on a low salt diet), } \\
\text { measurements were performed } \\
\text { at the end of treatment period }\end{array}$ & - & $\begin{array}{l}\text { Results revealed significantly } \\
\text { augmented expression of TGF } \beta 1 \\
\text { in renal tubular cells induced by } \\
\text { chronic cyclosporine A } \\
\text { administration (45) }\end{array}$ \\
\hline & $\begin{array}{l}\text { Sprague-Dawley/ふ/ } \\
\text { 180g-240g }\end{array}$ & $\begin{array}{l}15 \mathrm{mg} \text { Cyclosporine } \mathrm{A} / \mathrm{kg} / \mathrm{day} \\
\text { by a daily gavage for } 12 \text { weeks, } \\
\text { measurements were performed } \\
\text { at the end of treatment period }\end{array}$ & $\begin{array}{l}\text { Eplerenone administration-tablets } \\
\text { of } 50 \mathrm{mg} \text { by p.o., } 1,2 \mathrm{mg} / \mathrm{g} \text { dry } \\
\text { food approximating a daily dose } \\
\text { of } 100 \mathrm{mg} / \mathrm{kg} \text { body weight }\end{array}$ & $\begin{array}{l}\text { Eplerenone administration showed } \\
\text { a preventive effect in the } \\
\text { development of renal fibrosis (59) }\end{array}$ \\
\hline & $\begin{array}{c}\text { Sprague-Dawley/ } / \hat{l} \\
200-230 \mathrm{~g}\end{array}$ & $\begin{array}{l}15 \mathrm{mg} \text { Cyclosporine } \mathrm{A} / \mathrm{kg} / \mathrm{day} \\
\text { by gavage for } 28 \text { days } \\
\text { (after } 1 \text { week on low salt diet), } \\
\text { measurements were performed } \\
\text { at the end of treatment period }\end{array}$ & $\begin{array}{c}80 \mathrm{mg} \text { Tea polyphenols/ } \\
\mathrm{kg} / \mathrm{day} \text { by gavage after } 1 \text { week } \\
\text { on low salt diet }\end{array}$ & $\begin{array}{l}\text { Tea polyphenol administration } \\
\text { reduced TGF } \beta 1 \text { expression and } \\
\text { renal fibrosis in a rat model } \\
\text { of chronic cyclosporine } \\
\text { A administration (103) }\end{array}$ \\
\hline & $\begin{array}{c}\text { Sprague-Dawley/ } \\
\delta^{\top} / 230-250 \mathrm{~g}\end{array}$ & $\begin{array}{l}\text { Three distinct studies were } \\
\text { performed ( } 15 \mathrm{mg} \text { cyclosporine } \\
\text { A/kg/day by a daily s.c.): } \\
\text { 1: cyclosporine A for } 4 \text { weeks; } \\
\text { 2: cyclosporine A for } 1 \text { week, and } \\
\text { then replaced by sirolimus } \\
\text { (early conversion); } 3 \text { : cyclosporine } \\
\text { A for } 4 \text { weeks and then replaced } \\
\text { by sirolimus for } 4 \text { weeks } \\
\text { (late conversion). Measurements } \\
\text { were performed at the } \\
\text { end of treatment period }\end{array}$ & $\begin{array}{c}0,3 \mathrm{mg} \text { Sirolimus } / \mathrm{kg} / \mathrm{day} \text { by } \\
\text { a daily s.c. according to } \\
\text { the study performed }\end{array}$ & $\begin{array}{l}\text { Early conversion from cyclosporine } \\
\text { A to sirolimus was effective in } \\
\text { inhibiting cyclosporine A- } \\
\text { induced renal damage (60) }\end{array}$ \\
\hline & $\begin{array}{l}\mathrm{ICR} / \delta / 9 \text { weeks/ } \\
\text { with } \mathrm{Nrf} 2+/+ \\
\text { or Nrf2-/- } \\
\text { genotype }\end{array}$ & $\begin{array}{l}\text { Animals were treated with } \\
\text { either olive oil }(5 \mathrm{ml} / \mathrm{kg} \text { ) } \\
\text { or olive oil-suspended } \\
\text { cyclosporine A ( } 30 \mathrm{mg} / \mathrm{kg}) \text { by } \\
\text { gavage for } 2 \text { weeks, samples } \\
\text { (blood and kidneys) were taken } \\
\text { at the end of treatment period }\end{array}$ & - & $\begin{array}{c}\text { Data demonstrated that the NRF2 } \\
\text {-heme oxygenase-1 system has a } \\
\text { protective role against cyclosporine } \\
\text { A-induced renal fibrosis by } \\
\text { modulating epithelial- } \\
\text { mesenchymal transition } \\
\text { gene changes ( } 97)\end{array}$ \\
\hline
\end{tabular}

i.v.: Intravenous; s.c.: subcutaneous; i.p.: intraperitoneal; p.o.: per os; $\mathrm{HgCl}_{2}$ : mercuric chloride; CKD: chronic kidney disease; TGF $\beta$ : transforming growth factor $\beta$; NRF2: nuclear factor E2-related factor 2.

68). In this model, the alterations to the matrix metabolic enzymes in the remnant kidney strengthen the idea that an imbalance of matrix generation/degradation may contribute to the development of renal damage and renal fibrosis following 5/6 renal mass ablation (9). Regardless of aetiology, the reduction in functioning renal mass is associated with progressive glomerulosclerosis (67). This fact makes the 5/6 nephrectomy model one of the most often-used in the study of glomerulosclerosis. However, this model is limited due to the difficulty of performing surgery, the high mortality rate and the sudden loss of a large amount of renal tissue that occurs very rarely in human disease, where loss of functional renal tissue typically occurs more gradually. 
in vivo $31: 1-22(2017)$

Table II. Surgical models used for renal fibrosis study - drugs evaluated and their efficacy.

\begin{tabular}{lcccc}
\hline $\begin{array}{l}\text { Surgical induction } \\
\text { method }\end{array}$ & $\begin{array}{c}\text { Strain/gender/ } \\
\text { age, weight }\end{array}$ & Protocol & $\begin{array}{c}\text { Drugs and } \\
\text { compounds evaluated }\end{array}$ & $\begin{array}{c}\text { Results and therapeutic } \\
\text { effects (reference) }\end{array}$ \\
\hline
\end{tabular}

5/6 Renal mass Sprague-Dawley/ In the first step, two poles Mycophenolate mofetil and reduction (two $\quad \delta / 280-300 \mathrm{~g}$ surgical times)

$\begin{array}{lc} & \text { Wistar/\&/ } \\ & 150-170 \mathrm{~g}\end{array}$
the right kidney was removed
5/6 Renal mass reduction (one surgical time with the removal of the right kidney alone) of the left kidney were

removed and one week later In the first step, two poles of the left kidney were removed and three days later the right kidney was removed. Diuresis experiments were performed 1, 4, 8, 10, 20 weeks after 5/6 nephrectomy In the first step, two poles of the left kidney were removed and one week later the right kidney was removed 5/6 Nephrectomy was performed by ligation of two or three branches of the left renal artery and right nephrectomy 5/6 Nephrectomy was performed by ligation of two of three branches of the left renal artery and right nephrectomy 5/6 Nephrectomy was performed by removing the whole right kidney and upper and lower poles of the left kidney

5/6 Nephrectomy was performed by removing the whole right kidney and upper and lower poles of the left kidney

The lower branch of the left renal artery was ligated

to produce about one third area with visible renal ischemia; the upper pole of the left kidney was removed by cautery and the right kidney was nephrectomized to induce a total 5/6 nephrectomy. In some C57BL/6 mice, 7/8 nephrectomy was induced by removing additional renal mass from the upper pole of the left kidney by cautery

Sprague-Dawley/ $\delta^{\pi} / 182-206 \mathrm{~g}$ Renal mass reduction was performed, with the removal of the right kidney alone
Vitamin E by oral gavage 5,000 IU $\alpha$-tocopherol $/ \mathrm{kg}$ chow for 15 weeks

$0.2 \mathrm{mg}$ Halofugione $/ \mathrm{kg} /$ day by oral gavage for 8 weeks

Rehmannia glutinosa p.o. administration of the aqueous extract $500 \mathrm{mg} / \mathrm{kg} /$ day for 8 weeks

Animals received gene therapy with doxycycline-inducible Smad7 or empty vectors mediated by an ultrasoundmicrobubble technique

Fasudil + aldosterone s.c., after 2 weeks of recovery from surgery, rats were treated for 5 weeks with: (1) Vehicle; (2) aldosterone $(0.75 \mu \mathrm{g} / \mathrm{h}) ;$ aldosterone + fasudil ( $10 \mathrm{mg} / \mathrm{kg} /$ day $)$
Mycophenolate mofetil and benazepril alone, and especially combined, improve

tubulointerstitial fibrosis (9)

Did not cause any fibrotic alterations during the 20-week study period (29)

Long-term vitamin E therapy reduced renal fibrosis (95)

Endoglin expression was increased in rats with renal fibrosis (7) Halofuginone reduced
renal fibrosis (89)

Rehmannia glutinosa reduced renal fibrosis principally by inhibiting the expression of Ang II and AT1 receptors, TGF $\beta 1$, and type IV collagen (43)

Ang II induces renal fibrosis via the TGF $\beta$ by a SMAD signalling pathway (30)

Genetic background is one of the significant factors that determines a predisposition to the progression of glomerulosclerosis in mice (65)

Fasudil significantly diminished aldosterone-induced renal fibrosis (93) 
Table II. Continued

\begin{tabular}{|c|c|c|c|c|}
\hline $\begin{array}{l}\text { Surgical induction } \\
\text { method }\end{array}$ & $\begin{array}{c}\text { Strain/gender/ } \\
\text { age, weight }\end{array}$ & Protocol & $\begin{array}{c}\text { Drugs and } \\
\text { compounds evaluated }\end{array}$ & $\begin{array}{l}\text { Results and therapeutic } \\
\text { effects (reference) }\end{array}$ \\
\hline \multirow[t]{7}{*}{ UUO } & 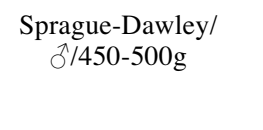 & $\begin{array}{l}\text { UUO was performed by } \\
\text { left unilateral } \\
\text { ureteral ligation }\end{array}$ & $\begin{array}{l}\text { Losartan in drinking water } 1 \\
\text { day before UUO and continued } \\
\text { daily until the animals were } \\
\text { sacrificed on day } 21(250 \mathrm{mg} / 1)\end{array}$ & $\begin{array}{l}\text { Ang II blockade with losartan } \\
\text { considerably decreased } \\
\text { renal injury, and improved } \\
\text { renal fibrosis }(76)\end{array}$ \\
\hline & $\begin{array}{c}\mathrm{B} 1^{+/+} \text {and } \mathrm{B} 1^{-/-/ ふ} \text {; } \\
\text { C57BL/6/ठో/ } \\
\text { 8-12 weeks }\end{array}$ & $\begin{array}{l}\text { UUO was performed } \\
\text { by left unilateral } \\
\text { ureteral ligation }\end{array}$ & $\begin{array}{l}\text { Kinin B1 receptor antagonist } \\
\text { by oral gavage in aqueous } \\
\text { solution } 1 \text { day before obstruction } \\
\text { or } 3 \text { days after and continued } \\
\text { throughout the time of obstruction } \\
\quad(10 \mathrm{mg} \text { kinin B1 receptor } \\
\text { antagonist SSR } 240612 / \mathrm{kg} / \text { day })\end{array}$ & $\begin{array}{l}\text { Kinin B1 receptor blockade } \\
\text { reduced the development } \\
\text { of renal fibrosis (74) }\end{array}$ \\
\hline & $\begin{array}{l}\text { Isogenic kinin } 1 \\
\text { receptor-deficient } \\
\text { C57BL/6/ } \widehat{\jmath}, \\
\text { wild-type C57BL/6/ } \\
\delta / 8 \text { weeks } 25-28 \mathrm{~g}\end{array}$ & $\begin{array}{l}\text { UUO was performed } \\
\text { by left unilateral ureteral } \\
\text { ligation. Experimental } \\
\text { protocol was performed } \\
\text { at days } 1,5 \text { and } \\
14 \text { after UUO }\end{array}$ & - & $\begin{array}{l}\text { Kinin B1 receptor removal } \\
\text { may be a significant } \\
\text { factor in renal fibrosis } \\
\text { prevention (44) }\end{array}$ \\
\hline & $\begin{array}{l}\text { Adult (12 to } 20 \\
\text { weeks) or young } \\
\text { (P12 - neonates } \\
12 \text { days after } \\
\text { birth) C57BL/6 } \\
\text { or coll-GFP }\end{array}$ & $\begin{array}{l}\text { UUO was performed } \\
\text { through a left flank incision. } \\
\text { The ureter was identified } \\
\text { and tied at the level of } \\
\text { the lower pole of the kidney } \\
\text { with two separate silk ties }\end{array}$ & - & $\begin{array}{l}\text { Study of the differentiation of } \\
\text { pericytes and into myofibroblasts } \\
\text { in the ureteral obstruction } \\
\text { model of renal fibrosis. Renal } \\
\text { fibrosis research should focus } \\
\text { on injury of the vasculature rather } \\
\text { than injury to the epithelium (41) }\end{array}$ \\
\hline & $\begin{array}{l}\text { C57BL/6 (wild-type)/ } \\
\text { क/10 wk } 20 \mathrm{~g}-22 \mathrm{~g} ; \\
\text { T1a-deficient (mutant)/ } \\
\text { क/10 weeks } 25 \mathrm{~g}-25 \mathrm{~g}\end{array}$ & $\begin{array}{c}\text { UUO was performed } \\
\text { by the left ureter ligation, } \\
\text { kidneys were harvested } \\
\text { at } 2,5 \text {, and } 10 \text { days } \\
\text { after UUO for } \\
\text { histological evaluation }\end{array}$ & - & $\begin{array}{l}\text { Ang II plays a central role in the } \\
\text { development of tubulointerstitial } \\
\text { fibrosis via the AT1 } \\
\text { receptor in UUO (75) }\end{array}$ \\
\hline & $\begin{array}{l}\text { TWEAK deficient } \\
\text { or wild type C57BL/ } \\
6 / 10 \text { to } 14 \text {-weeks }\end{array}$ & $\begin{array}{l}\text { UUO was performed } \\
\text { by the left ureter ligation, } \\
\text { kidneys were harvested } \\
\text { at } 48 \mathrm{~h}, 7,14 \text { or } 21 \\
\text { days after surgery for } \\
\text { histological studies }\end{array}$ & - & $\begin{array}{l}\text { Deletion of TWEAK reduced } \\
\text { renal fibrosis by Ras } \\
\text { pathway (48) }\end{array}$ \\
\hline & $\begin{array}{l}\text { C57BL/6/ふ/ } \\
2 \text { months }\end{array}$ & $\begin{array}{l}\text { UUO was performed } \\
\text { by the left ureter ligation, } \\
\text { kidneys were harvested } \\
\text { according to the treatment } \\
\text { and group of the study }\end{array}$ & $\begin{array}{c}0.8 \mathrm{mg} \text { Ang II } / \mathrm{kg} \text { by a single } i . p . ; \\
40 \mathrm{mg} \text { losartan } / \mathrm{kg} \text { by a daily } \\
\text { i.p.; } 70 \mathrm{mg} \text { atorvastatin } / \mathrm{kg} / \mathrm{day} \\
\text { by oral gavage; } 40 \mathrm{mg} \text { farnesyl } \\
\text { transferase inhibitor } / \mathrm{kg} \text { s.c.; } 3 \mathrm{mg} \\
\text { chaetomellic acid } \mathrm{A} / \mathrm{kg} / \mathrm{day} \text { s.c. }\end{array}$ & $\begin{array}{l}\text { Inhibition of RAS pathway } \\
\text { activation may be a therapeutic } \\
\text { target in the prevention } \\
\text { of renal fibrosis }(100)\end{array}$ \\
\hline \multirow[t]{3}{*}{ Ischaemia } & $\begin{array}{l}\text { Wistar/q/ } \\
150-170 \mathrm{~g}\end{array}$ & $\begin{array}{l}\text { The left kidney was laid } \\
\text { bare and the renal artery } \\
\text { was ligated for } 20 \text { or } 45 \text { min. } \\
\text { Diuresis experiments were } \\
\text { performed } 8,12,16,20 \\
\text { weeks after ischaemia }\end{array}$ & - & $\begin{array}{l}\text { Ischaemia did not cause } \\
\text { significant fibrotic } \\
\text { alterations during the } \\
\text { 20-week study period (29) }\end{array}$ \\
\hline & $\begin{array}{c}\text { C57BL/6/ふ/ } \\
\text { 7-9 weeks } 20-25 \mathrm{~g}\end{array}$ & $\begin{array}{l}\text { Animals were subjected } \\
\text { to either } 45 \text { or } 60 \text { minutes } \\
\text { of unilateral kidney ischemia. } \\
\text { Diuresis experiments and } \\
\text { fibrosis evaluation were } \\
\text { performed } 4 \text { weeks } \\
\text { after ischaemia }\end{array}$ & $\begin{array}{l}1.5 \mathrm{mg} \text { Rapamycin } / \mathrm{kg} / \mathrm{day} \\
\text { s.c. starting } 1 \text { week after } \\
\text { surgery for up to } 3 \text { weeks }\end{array}$ & $\begin{array}{l}\text { Delayed treatment of rapamycin } \\
\text { after an ischemia reperfusion } \\
\text { injury had an insignificant } \\
\text { effect on renal fibrosis (78) }\end{array}$ \\
\hline & $\begin{array}{l}\text { dult ( } 12 \text { to } 20 \text { weeks) } \\
\text { or young (P12- } \\
\text { neonates } 12 \text { days } \\
\text { after birth) C57BL/6 } \\
\text { or coll-GFP }\end{array}$ & $\begin{array}{l}\text { Ischemia reperfusion injury } \\
\text { was performed through a } \\
\text { left flank incision. A surgical } \\
\text { clamp was placed over the } \\
\text { artery and vein for } 35 \text { minutes } \\
\text { and then removed. Return of } \\
\text { blood flow was confirmed. }\end{array}$ & - & $\begin{array}{l}\text { Study the differentiation of } \\
\text { pericytes into myofibroblasts } \\
\text { in the ischemia-reperfusion } \\
\text { model of renal fibrosis. Renal } \\
\text { fibrosis research should focus on } \\
\text { injury of the vasculature rather } \\
\text { than injury to the epithelium (41) }\end{array}$ \\
\hline
\end{tabular}

s.c.: Subcutaneous; i.p.: intraperitoneal; p.o.: per os; TGF $\beta$ : transforming growth factor- $\beta$; TWEAK: tumour necrosis factor-like weak inducer of apoptosis; Ang II: angiotensin II; AT1: angiotensin II type-1; UUO: unilateral ureteral obstruction; coll-GFP: collagen type I- $\alpha 1$ transcript. 
As a result of the renal mass reduction, the number of nephrons suddenly decreases and the remaining nephrons begin to develop renal damage, which depends on: the surgical method used; the amount of tissue removed; the strain and sex of the animal (67); and the experimental technique (1). Fleck and colleagues demonstrated that male rats are more resistant to 5/6 renal mass ablation than female rats, and suggest higher resistance in Sprague-Dawley rats to 5/6 renal mass ablation compared with Wistar rats, indicating that strain and gender influence the progression of renal disease in the experimental model of a 5/6 nephrectomy (69).

Unilateral ureteral obstruction. Obstructive uropathy is the main cause of end-stage renal disease in children of the United States, being one of the main reasons for paediatric kidney transplants (70). Urinary pathway obstruction, which may result either from the blockage of one or both ureters, provokes the progressive damage of renal structures, which leads to chronic renal dysfunction. Ureteral obstruction leads to kidney enlargement, caused by urine collecting in the renal pelvis or calyces, which causes hydronephrosis $(1,71)$. This situation therefore causes renal dysfunction by impeding the normal flow of urine through the renal pelvis, ureters, bladder and urethra (1). In rodents, UUO can be considered the most widely used model to study the mechanisms of non-immunological tubulointerstitial fibrosis (72). The surgical technique applied to achieve this animal model is relatively simple, if performed as a single process in an adult rats (17) and mice (31), with the ligation of the ureter being most frequentlyused technique [see Chevalier $e t$ al. (17)]. In general, the alterations caused by this model are established within 7 days in mice and 2-3 weeks in rats (4).

UUO is the most widely used interstitial fibrosis model, due to the rapid tubular atrophy and interstitial fibrosis development and matrix deposition (73). The UUO animal model and human obstructive nephropathies have very similar aetiology. However, this absolute obstruction very rarely occurs in humans, but due to its accelerated time course, this model reproduces a fibrotic sequence of events that is almost identical to that found in humans $(1,31)$. In UUO, the first alterations observed in the kidneys are haemodynamic, mainly triggered by the increased activity of the vasoconstrictor systems, namely the reninangiotensin system (72). After complete UUO in the obstructed kidney, there is a progressive decline in renal blood flow, glomerular filtration rate and rapid damage of the renal parenchyma. Most of the renal cellular alterations occur after 2-3 weeks (17), namely an increase in intratubular pressure, and consequently an extension of the tubule walls (31), epithelial tubular cell damage (72) and subsequently a significant increase in renal fibrosis indicators as inflammation mediated by macrophages (44, 74) and myofibroblasts (72). These cells produce cytokines and growth factors that trigger an inflammatory process in the kidney after UUO, inducing ECM deposition and cell apoptosis. Furthermore, oxidative stress and the renin-Ang II system play an important role in the overexpression of pro-inflammatory cytokines in the UUO. In this sense, it is fully established that TGF $\beta$ and NFKB play a central role in stimulating ECM production and in the inflammatory process after UUO, respectively (72). The pro-inflammatory kinin $\mathrm{B} 1$ receptor contributes to the development of UUOinduced renal inflammation and consequently renal fibrosis. In this way, Klein and colleagues (2009) showed that kinin B1 receptor blockade significantly reduced the progression of evident renal fibrosis in the UUO animal model. It seems that this effect was in part provoked by a mechanism related with the inhibition of CTGF and chemokine expression by resident renal cells and without altering TGF $\beta$ expression (74). Nevertheless, Wang and colleagues demonstrated that kinin B1 receptor deletion reduced renal fibrosis while improving expression of anti-inflammatory factors (heme oxygenase- 1 and interleukin-10) and reducing that of the pro-inflammatory factors (TGF $\beta$ and interleukin-6) (44). These results demonstrate that $\mathrm{B} 1$ receptor blockade reduces renal fibrosis by modifying the expression of the immune components, however certain effects/processes involved remain to be determined.

An imbalance between vasoconstricting and vasodilating substances may demonstrate haemodynamic changes observed in the UUO model. This leads to the activation of the plasma and renal renin-angiotensin-aldosterone system, triggering subsequent pathological alterations through the activation of TGF $\beta$ and NFKB (75), the infiltration of immune cells, fibrosis and renal hypoperfusion (31), and the overexpression of CTGF (74). Indeed, as demonstrated in several studies, renal Ang II is the crucial mediator of the renal response to UUO, including inflammation, apoptosis, interstitial fibrosis $(17,31,75,76)$, and increased fibroblast expression (76). In a study by Kellner and colleagues, the losartan angiotensin receptor antagonist considerably reduced renal injury in the UUO model, improving apoptosis, renal fibrosis, fibroblast and macrophage expression infiltration, and thus demonstrating the effectiveness of this type of treatment. About $50 \%$ of the renal alterations were not affected by this treatment, indicating that there are other factors in the development of renal injury in UUO. However, these facts suggest that Ang II is responsible for around 50\% of the renal fibrotic response in UUO (76). Total UUO is a pathological condition that causes tubular atrophy, proliferation and apoptosis of the epithelial tubular cells, macrophage infiltration, epithelial-mesenchymal transition, interstitial cell infiltration, ECM deposition, collagen I deposition and an accumulation of fibroblasts and myofibroblasts (31). Lin and colleagues identified the pericytes and fibrocytes as two sources of collagen I in the 
Table III. Spontaneous models used for renal fibrosis study.

\begin{tabular}{|c|c|c|c|}
\hline Animals & Strain/gender/age & Protocol & Results (reference) \\
\hline Buffalo/Mna & $\begin{array}{c}\text { Buffalo/Mna/ } \\
6 \text { months }\end{array}$ & $\begin{array}{l}\text { Kidneys from healthy LEW.1W }\left(\mathrm{RT} 1^{\mathrm{u}}\right) \\
\text { were grafted into 6-month-old proteinuric } \\
\left.\text { Buffalo/Mna (RT1 } 1^{\mathrm{u}}\right) \text { using a protocol of } \\
\text { tolerance stimulation by donor-specific transfusion }\end{array}$ & $\begin{array}{l}\text { Proteinuria decreased in healthy kidneys grafted } \\
\text { into Buffalo/Mna recipients. Buffalo/Mna rats } \\
\text { are suitable for the study of renal fibrosis } \\
\text { and an interesting animal model for relapsing } \\
\text { segmental glomerulosclerosis in humans (47) }\end{array}$ \\
\hline $\begin{array}{l}\text { Munich Wistar } \\
\text { Frömter }\end{array}$ & $\begin{array}{l}\text { Munich Wistar } \\
\text { Frömter and Wistar/ } \\
\text { †/ठ/12-14 weeks }\end{array}$ & $\begin{array}{l}\text { Diuresis experiments and fibrosis evaluation } \\
\text { were performed in these animals }\end{array}$ & $\begin{array}{l}\text { Data suggests that male Munich Wistar } \\
\text { Frömter rats spontaneously developed } \\
\text { proteinuria and glomerulosclerosis with } \\
\text { age, which appeared to be associated } \\
\text { with a lower number of nephrons (46) }\end{array}$ \\
\hline
\end{tabular}

UUO of renal fibrosis (41), also showing that pericytes are the source of myofibroblasts, highlighting the key role that pericytes play in the development of renal fibrosis $(41,77)$. In another study, absence of tumour necrosis factor-like weak inducer of apoptosis (TWEAK) delayed the accumulation of myofibroblasts and reduced ECM deposition in the UUO mouse model. On the other hand, TWEAK overexpression promoted renal fibrosis in mice without any kidney damage (48). These results showed the fibrotic actions of TWEAK that should be further investigated in order to understand the mechanisms of a chronic persistent kidney injury model such as the UUO model.

However, in this model, the recovery time following the removal of the obstruction is inversely proportional to the duration of the obstruction. On the one hand, in the UUO, one of the first consequences of peritubular capillary destruction, tubular atrophy and progressive renal insufficiency is renal interstitial matrix accumulation. However, on the other hand, renal inflammation leads to glomerular and tubular damage in some nephrons, which in turn leads to the damage of the remaining nephrons, demonstrating that interstitial fibrosis is a secondary expression of the disease (17).

Animal UUO models can be used in research to obtain new therapeutic options for the more effective treatment of renal fibrosis, e.g. mouse models, which have the advantage of genetic manipulation of species (31). This is especially so since this model has a rapid time course (6), does not use exogenous toxins, lacks the 'uremic' environment, allows for variations in the severity, timing, and duration of obstruction (17), has good reproducibility, easy performance, availability of the contralateral kidney as a control factor and is specific strain independent (23). However, this model does have some deficiencies, for example, the incapacity to monitor changes in renal function, because the unobstructed contralateral kidney offsets the loss in renal function (6), and as it is realized with acute injury, may not be indicated for the study of all conditions of renal fibrosis (4).
Ischaemia-reperfusion. The ischemia-reperfusion model is performed in rats through median abdominal incision: the left kidney is laid bare and the renal artery is ligated for 20 or 45 min in Wistar rats (29), and in C57BL/6 mice by 45 or 60 min of unilateral kidney ischemia (78). After one day, the right kidney is removed via a dorsal incision to eliminate the compensatory effects of the contralateral kidney. Kidney samples from the rats taken 20 weeks after 20 and 45 min ischaemia did not show significant interstitial fibrosis. Some kidney samples exhibited atrophic tubules and revealed a slightly thickened tubular basement membrane (29). Takada et al. similarly demonstrated that the morphological changes occurring predominantly between 20 and 40 weeks after renal ischaemia are glomerulosclerosis and interstitial fibrosis (79). Ischemia duration is also very important since the almost-complete recovery of renal function and morphology has been observed in rats 4 weeks after $30 \mathrm{~min}$ ischaemia (80).

\section{Spontaneous Models of Renal Fibrosis}

There are several references in literature indicating that certain mouse and rat strains may be more vulnerable to the development and progression of renal disease and provide the opportunity to investigate new mechanisms and new genes that lead to spontaneous renal fibrosis. Thus, genetic background plays an important role in the response to renal injuries $(65,81)$. Wistar-Kyoto (WKY)/NCrj and ACI/NMs rats are resistant to glomerulosclerosis, and male $\mathrm{PVG} / \mathrm{c}$ rats are totally resistant to glomerulosclerosis. On the other hand, male Wistar rats are predisposed to the spontaneous development of glomerulosclerosis, and approximately $100 \%$ of Buffalo/Mna strain rats spontaneously develop glomerulosclerosis over time (65) (Table III).

Buffalo/Mna rats. Between 2 and 4 months of age Buffalo/Mna rats spontaneously develop podocyte alterations, proteinuria, but without verification of sclerotic 
in vivo $31: 1-22(2017)$

Table IV. Genetic models used for renal fibrosis study - drugs evaluated and their efficacy.

\begin{tabular}{|c|c|c|c|c|}
\hline Animals & $\begin{array}{l}\text { Strain/gender/ } \\
\text { age/weeks }\end{array}$ & Protocol & $\begin{array}{c}\text { Drugs and } \\
\text { compounds evaluated }\end{array}$ & $\begin{array}{l}\text { Results and therapeutic } \\
\text { effects (reference) }\end{array}$ \\
\hline Nep 25 mice & $\begin{array}{l}\text { Nep 25// } \\
6-15 \text { weeks }\end{array}$ & $\begin{array}{l}\text { LMB2 } 1.25 \text { to } 50 \mathrm{ng} / \mathrm{g} \\
i . v . \text {, data were performed } \\
\text { for } 28 \text { days }\end{array}$ & - & $\begin{array}{l}\text { Nep } 25 \text { mice dose-dependently } \\
\text { developed proteinuria, glomerular } \\
\text { injury and renal fibrosis }(84)\end{array}$ \\
\hline $\begin{array}{l}\text { HIVAN } \\
\text { transgenic } \\
\text { mice }\end{array}$ & $\begin{array}{l}\text { HIVAN transgenic } \\
\text { Tg26/heterozygous } \\
\text { transgenic and non- } \\
\text { transgenic/21 day }\end{array}$ & $\begin{array}{l}\text { Twenty-four sets of these } \\
\text { groups entered and } \\
\text { completed the 20-day } \\
\text { drug treatment protocol. } \\
\text { Chemical and histological } \\
\text { analyses were performed } \\
\text { after treatment }\end{array}$ & $\begin{array}{c}2.5 \mathrm{mg} \text { Flavopiridol } / \mathrm{kg} \text { or an } \\
\text { equivalent volume of vehicle } \\
\text { i.p. every } 12 \mathrm{~h} \text { for } 20 \text { days }\end{array}$ & $\begin{array}{l}\text { Flavopiridol improved the focal } \\
\text { glomerulosclerosis in HIVAN } \\
\text { transgenic mice (104) }\end{array}$ \\
\hline $\begin{array}{l}\text { Transgenic } \\
\text { mice expressing } \\
\text { EGFP }\end{array}$ & $\begin{array}{c}\text { Adult (12 to } 20 \\
\text { weeks) or young } \\
\text { (P12 - neonates } \\
12 \text { days after birth) } \\
\text { C57BL/6 or coll-GFP }\end{array}$ & $\begin{array}{l}\text { Transgenic mice expressing } \\
\text { EGFP in cells producing } \\
\text { coll-GFP. This mouse model } \\
\text { is used to study } \\
\text { collagen-producing cells } \\
\text { in kidney disease }\end{array}$ & - & $\begin{array}{c}\text { In normal kidneys, both podocyte } \\
\text { and pericytes produce Coll1a1 } \\
\text { transcripts, and that in fibrotic } \\
\text { kidneys, Coll1a1-GFP } \\
\text { expression indeed identifies } \\
\text { myofibroblasts (41) }\end{array}$ \\
\hline $\begin{array}{l}\text { Collagen- } \\
\text { receptor } \\
\text { deletion Ddr1 }\end{array}$ & $\begin{array}{l}\text { Collagen-receptor } \\
\text { deletion } D d r 1 / \text { both } \\
\text { sexes } / 7.5 \text { or } \\
9.5 \text { weeks }\end{array}$ & 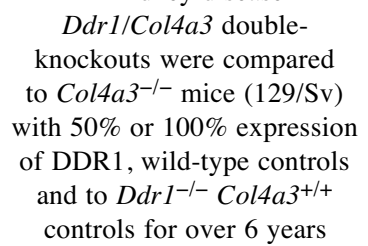 & - & $\begin{array}{l}\text { Absence of DDR1-expression in } \\
\text { the kidney reduced renal } \\
\text { fibrosis and inflammation (98) }\end{array}$ \\
\hline $\begin{array}{l}\text { AT1a receptor- } \\
\text { deficient } \\
\text { C57BL/6 mice }\end{array}$ & $\begin{array}{l}\text { AT1a receptor- } \\
\text { deficient C57BL/6 } \\
/ 9 / 10 \text { weeks/ } \\
25 \mathrm{~g}-35 \mathrm{~g}\end{array}$ & $\begin{array}{l}\text { These animals were subjected } \\
\text { to UUO. Kidneys were } \\
\text { harvested at } 2,5 \text {, and } 10 \text { days } \\
\text { for histological evaluation }\end{array}$ & - & $\begin{array}{l}\text { Results showed that the alteration } \\
\text { indicative of renal fibrosis observed } \\
\text { in receptor-deficient AT1 a C57BL/6 } \\
\text { mice were lower than those } \\
\text { detected in mice with UUO ( } 75)\end{array}$ \\
\hline
\end{tabular}

i.v.: Intravenous; i.p.: intraperitoneal; Nep25: transgenic mouse strain; HIVAN: HIV-associated nephropathy; coll-GFP: collagen type I- $\alpha 1$ transcript; DDR1: discoidin domain receptor 1; EGFP: enhanced green fluorescent protein; UUO: unilateral ureteral obstruction; AT1: angiotensin II type-1.

glomeruli. At the age of 6 months, these animals had a few sclerotic glomeruli in all sections of kidney examined. At 22 months of age, about $37.8-52.1 \%$ of the glomeruli became sclerotic (82). These rats are suitable for use as animal models to investigate renal fibrosis in humans (23).

Munich. Munich Wistar Frömter rats have a congenital deficit with approximately $30-50 \%$ fewer nephrons than normal, and structural changes (sclerosis) that develop spontaneously with age (23). By the age of 10 weeks, these rats develop proteinuria, and by week 35 the kidneys demonstrate marked glomerulosclerosis (83). In these animals, aging is also associated with a progressive increase in blood pressure. This situation is more noticeable in females than in males. However, males and females have a similar glomeruli number per kidney. This gender-related difference can be explained by the higher single nephron filtration rate and glomerular volume verified in males when compared to females $(46,83)$. These rats are animal models to investigate renal fibrosis in humans; they allow us to study the progression of renal disease associated with a reduction in the number of nephrons $(23,46)$.

\section{Genetically Modified Models of Renal Fibrosis}

Renal fibrosis is much more difficult to induce in mice than in rats, since mice demonstrate greater resistance to experimental techniques. Thus, it is important to develop a mouse model in which renal fibrosis can be induced by a simple and unique procedure (84). Here, we describe four animals genetically modified for this purpose (Table IV).

Transgenic mouse strain (Nep25). Nep 25 mice exhibit genetically modified podocytes expressing a toxin receptor, being selectively diminished by single intravenous injection of anti-Tac (Fv)-PE38 (LMB2), a specific toxin, which led to selective and irreversible damage in the podocytes. Thus, the severity of disease can be controlled by the dose of toxin administered and knowledge of the exact time and location of the onset of the disease. After this injection, transgenic mice 
Table V. In vitro models used for renal fibrosis study - drugs evaluated and their efficacy.

\begin{tabular}{|c|c|c|c|}
\hline Cells & Protocol & $\begin{array}{c}\text { Drugs and } \\
\text { compounds evaluated }\end{array}$ & $\begin{array}{l}\text { Results and therapeutic } \\
\text { effects (reference) }\end{array}$ \\
\hline $\begin{array}{l}\text { Cultured rat } \\
\text { mesangial cells }\end{array}$ & $\begin{array}{l}\text { Rat mesangial cells were obtained } \\
\text { from intact glomeruli from 4-6 } \\
\text { week-old Sprague-Dawley rats }\end{array}$ & - & $\begin{array}{l}\text { Ang II induces TGF } \beta \text { production and } \\
\text { secretion by mesangial cells and TGF } \beta \\
\text { in turn stimulates ECM production (12) }\end{array}$ \\
\hline $\begin{array}{l}\text { Cultured rat kidney } \\
\text { tubular epithelial cell }\end{array}$ & NRK52E line & - & $\begin{array}{l}\text { Ang II induces the activation of the } \\
\text { Smad } 2 / 3 \text { and mitogen-activated protein } \\
\text { kinase pathways, as well as the expression } \\
\text { of CTGF, TGF } \beta 1 \text {, and collagen I ( } 30)\end{array}$ \\
\hline $\begin{array}{l}\text { Cultured rat } \\
\text { mesangial cells }\end{array}$ & $\begin{array}{l}\text { Rat mesangial cells were obtained } \\
\text { from Sprague-Dawley rats/ } \\
\text { stimulation with aldosterone } \\
(1 \mathrm{nmol} / \mathrm{l}) \text { induced myofibroblastic } \\
\text { differentiation and collagen gene } \\
\text { expression in rat mesangial cells }\end{array}$ & $\begin{array}{l}\text { Pre-incubation with a selective } \\
\text { mineralocorticoid receptor } \\
\text { antagonist eplerenone }(10 \mu \mathrm{mol} / \mathrm{l}) \\
\text { or a specific Rho-kinase inhibitor, } \\
\text { Y27632 }(10 \mu \mathrm{mol} / \mathrm{l})\end{array}$ & $\begin{array}{l}\text { Pre-treatment with eplerenone or Y27632 } \\
\text { prevented the aldosterone-induced } \\
\text { cell hypertrophy, promoting an } \\
\text { increase in collagen gene expression } \\
\text { via the Rho-kinase dependent } \\
\text { signalling pathway (88) }\end{array}$ \\
\hline $\begin{array}{l}\text { Cultured mice renal } \\
\text { fibroblast cells }\end{array}$ & $\begin{array}{l}\text { Mice renal interstitial fibroblast } \\
\text { cells originally isolated from SJL } \\
\text { mouse kidney/Murine embryonic } \\
\text { fibroblasts were isolated from mouse } \\
\text { embryos at } 10 \text { days post-coitum }\end{array}$ & - & $\begin{array}{c}\text { Results suggests that TWEAK } \\
\text { overexpression may promote renal } \\
\text { fibrosis by increasing inflammatory } \\
\text { activity and proliferation in } \\
\text { cultured renal fibroblasts (48) }\end{array}$ \\
\hline $\begin{array}{l}\text { Cultured murine } \\
\text { embryonic fibroblasts } \\
\text { and normal rat kidney } \\
\text { tubular epithelial cells }\end{array}$ & $\begin{array}{l}\text { Murine embryonic fibroblasts } \\
\text { from wild-type and } \\
\text { NRF2-deficient mice } \\
\text { and NRK52E }\end{array}$ & $\begin{array}{l}\text { Cells were treated with cyclosporine } \\
\text { A }(2,4 \text {, and } 8 \mu \mathrm{M}) \text { for } 48 \mathrm{~h} \\
\text { and NRK52E cells were treated } \\
\text { with sulforaphane (an activator } \\
\text { of NRF2) for } 24 \mathrm{~h} \text { then } \\
\text { incubated with vehicle } \\
\text { (ethanol) or cyclosporine } \\
\mathrm{A}(8 \mu \mathrm{M}) \text { for } 48 \mathrm{~h}\end{array}$ & $\begin{array}{l}\text { Cyclosporine A treatment } \\
\text { increased heme oxygenase-1 } \\
\text { expression in an NRF2-dependent } \\
\text { mode in normal rat kidney cells } \\
\text { as well as in murine fibroblasts. } \\
\text { Genetic inhibition of NRF2 in these } \\
\text { cells intensified alterations in } \\
\text { cyclosporine A-induced epithelial- } \\
\text { mesenchymal transition indicators (97) }\end{array}$ \\
\hline
\end{tabular}

Ang II: Angiotensin II; TGF $\beta$ : transforming growth factor- $\beta$; ECM: extracellular matrix; NRK52E: normal rat kidney tubular epithelial cells; CTGF: connective tissue growth factor; TWEAK: tumour necrosis factor-like weak inducer of apoptosis; NRF2: nuclear factor E2-related factor 2.

dose-dependently developed proteinuria and glomerular damage and subsequently renal fibrosis (84). Renal fibrosis in these transgenic mice and renal human fibrosis have similarities, and they can therefore be used to study podocytopathies (23).

HIV-associated nephropathy (HIVAN) transgenic mouse model. The HIVAN transgenic mouse model was developed using transgenic 26 mice ( $\mathrm{Tg} 26)$ with a defective HIV provirus as the integrated transgene $(23,85)$. HIVAN may be considered a rapidly progressive form of focal segmental glomerulosclerosis (86). At 24 days of age, these animals displayed proteinuria and $\mathrm{HIV}$-specific gene expression in the kidneys, and between 2 and 6 months of age a high mortality rate $(20 \%)$ and slight focal glomerulosclerosis were proven. Moribund animals demonstrate considerable glomerulosclerosis, microcystic tubular alteration and tubular epithelial degeneration, and interstitial nephritis, changes very similar to those found in human HIVAN $(23,85)$. Based on this Tg26 mouse model, a rat HIVAN model has also been developed which shows a more markedly expressed HIV transgene, however without glomerular collapse (23).
Coll-green fluorescent protein transgenic mice. Transgenic mice were generated expressing enhanced green fluorescent protein (EGFP) in cells producing the collagen type I- $\alpha 1$ (Coll1al) transcript (coll-GFP mice). Collagen I- $\alpha 1$ is the most abundant protein in collagen-I fibrils. These mice express a single copy of $3.5 \mathrm{~kb}$ of the 5' Colllal promoter, $0.5 \mathrm{~kb}$ of the 3' uncoded region and four upstream enhancers, driving EGFP expression, and have been shown to label collagen-I $\alpha 1$-producing cells with high sensitivity and specificity. This model is used to study collagen-producing cells in renal fibrosis (41).

AT1 receptor-deficient mice. Angiotensin AT1a receptordeficient C57BL/6 (mutant) mice have a targeted replacement of AT1a loci by the lacZ gene. These animals enable us to clarify the importance of AT1a-mediated signal transduction pathways in the pathophysiology of renal diseases, especially tubulointerstitial injury. Therefore, C57BL/6 (mutant) mice are useful in the study of the specific function of AT1a receptor (87). 


\section{In Vitro Models}

Nearly all intrinsic renal cells have been widely studied to assess specific mechanisms and signal pathways of renal fibrosis development. However, the results are incomplete, usually based on very specific aspects concerning only one cell type and very different from the complexity verified in renal fibrosis responses when studied in animal models (23) (Table V).

Cultured rat mesangial cells. Rat mesangial cells are used to study the physiopathological processes of renal disease in particular renal fibrosis, for example, the action of Ang II on TGF $\beta$ production and secretion by mesangial cells and the potential roles of Rho-kinase in aldosterone-induced mesangial cell hypertrophy $(12,88)$.

Cultured mouse renal fibroblast cells. Mouse renal fibroblast cells are used to study the molecular and cellular mechanisms promoting renal fibrosis. Cultured renal fibroblast cells can be used to evaluate the effect of tumour necrosis factor superfamily cytokines in the induction of the renal fibrosis process. Ucero and colleagues demonstrated that TWEAK induced inflammatory activity and proliferation in renal fibroblast cells, and this action has an RAS-dependent pro-proliferative and NFKB-dependent proinflammatory effects (48).

\section{Effective Treatments and New Perspectives of Research}

A very important factor in the preservation of renal function is the control of hypertension and hyperglycaemia (2). In humans, failure of kidney function caused by fibrosis generally happens many years after the onset of diabetes or recurrent infections. Although it is not possible to reproduce this phase in animal studies, the use of animal models for renal fibrosis allows for the evaluation of drug efficacy in the treatment of renal fibrosis and also the pathogenesis of this disease (25). However, there are few or no drugs with the capacity to prevent the fibrotic process in experimental and human CKD (89), not only in monotherapy but also with a combination of therapies, perhaps because renal fibrosis is a complex process that involves several cell types and mediators (90).

Treatments that target the renin-angiotensin-aldosterone system inhibition, carried out with two types of drugs: angiotensin-converting enzyme inhibitors and angiotensin receptor antagonists, are extremely effective in reducing proteinuria, CKD progression and renal fibrosis in humans and experimental models $(1,5,12,19)$. Indeed, Ang II is a principal mediator in the pathogenesis of renal disease (8). The use of higher doses of these two drugs can more effectively reduce fibrosis (32), and the benefits of this treatment are independent of blood pressure reduction (2). One of the factors leading to these effects by the blockage of the renin angiotensin system is indeed the reduction of the activity of $\operatorname{TGF} \beta(14,20)$ and also platelet-derived growth factors and PAI1 (5). In a study carried out in humans, losartan, an Ang II receptor blocker, diminished PAI1 in cyclosporine-treated renal graft recipients. Ang II blockage and PAI1 diminution may be an important action in preventing renal fibrosis (91). Currently, Ang II inhibition is clinically considered to be the most effective therapeutic intervention for preventing or reducing the development of most renal diseases (17). Although angiotensin-converting enzyme inhibition has widely recognized clinical benefits on the development of renal sclerosis, it is not equally effective at all stages of renal fibrosis, i.e. it is more effective in the earlier stages of sclerosis than in its advanced stages (5) (Figure 2).

Treatment with Rehmannia glutinosa inhibits the progression of glomerulosclerosis by reducing TGF $\beta$ mRNA expression and type IV collagen accumulation and is likely to prevent the presence of interstitial fibrosis and mononuclear cell infiltration (43). Pirfenidone, an antifibrotic molecule, attenuates renal fibrosis in the UUO model by reducing the level of TGF $\beta$ and the synthesis of collagen in the renal tissue, suggesting that pirfenidone may be applied as a treatment of renal fibrosis progression (92). However, despite the fact that anti-TGF $\beta$ therapies are associated with improved renal fibrosis $(2,7)$, it should be cautiously selected for regression of renal fibrosis because TGF $\beta$ is involved in the glomerular self-defence system that limits inflammation in renal injuries (20). On the other hand, a combination of TGF $\beta$ antibody with angiotensin-converting enzyme inhibitors offers superior nephroprotective effects than single treatments in that it normalizes blood pressure, proteinuria and led to regression of glomerulosclerosis and tubular injuries in rats (20). Blockade of the kinin B1 receptor is another promising antifibrotic therapy for renal fibrosis in animal models of obstructive nephropathy $(44,74)$. In another study, it was verified that the therapeutic combination of mycophenolate mofetil (immunosuppressive agent) and benazapril (angiotensin-converting enzyme inhibitor) was more effective in the treatment of renal fibrosis than mycophenolate mofetil and benazapril alone in 5/6 nephrectomized rats (9). Treatment with fasudil, a specific Rho-kinase inhibitor, significantly improved aldosteroneinduced renal fibrosis and increased collagen, TGF $\beta$, and CTGF expression as well as SMAD2/3 activity in the kidneys of rats which had undergone a right uninephrectomy (93). In another study, the effects of aldosterone were diminished by pre-treatment with a mineralocorticoid receptor antagonist and Rho-kinase inhibitor (88). This type of study, with a combination of two or more drugs, showed more effective results in several models of renal fibrosis, and should be considered as potential treatments. Nevertheless, further studies in animal models are required to confirm whether 


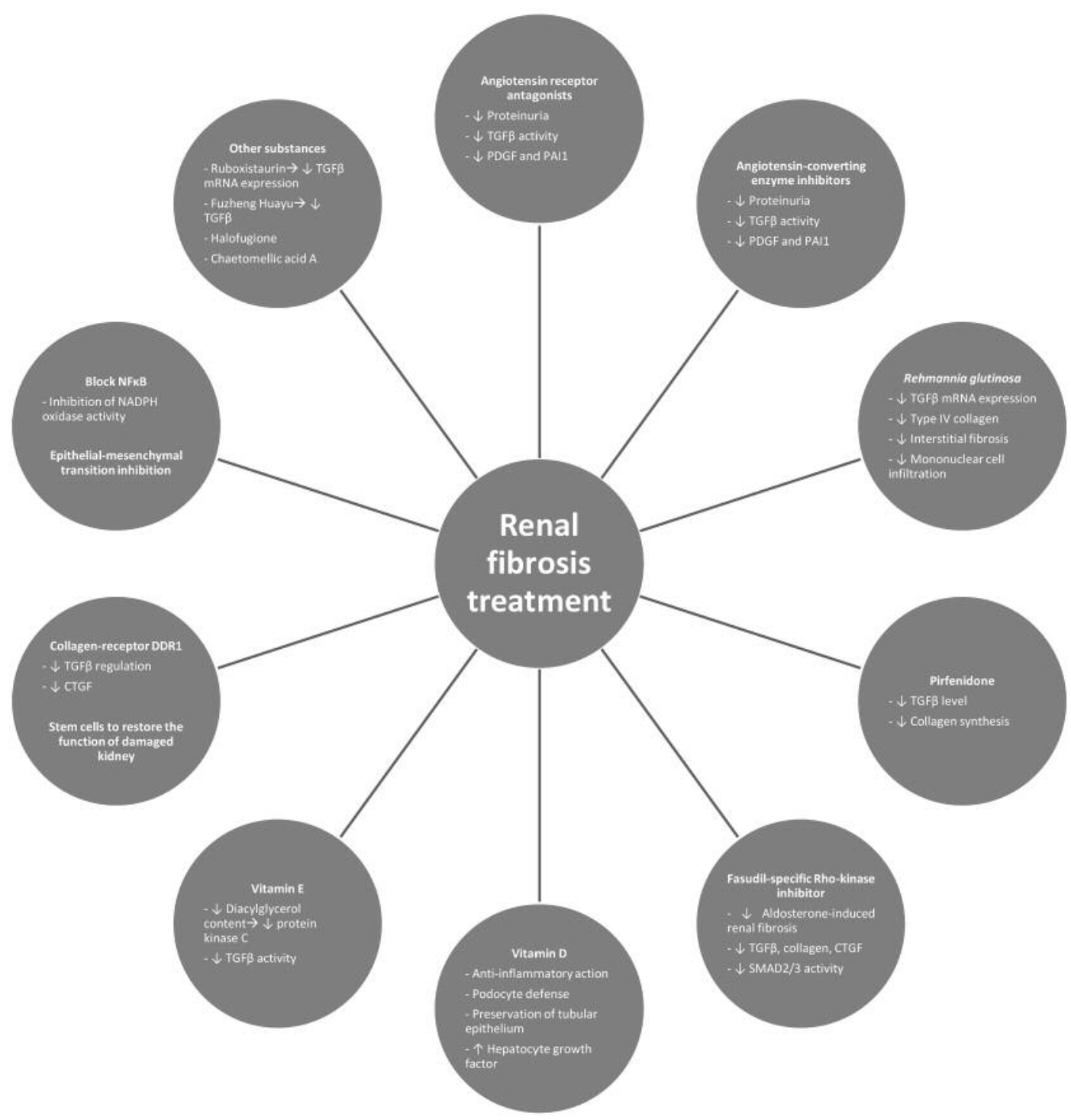

Figure 2. Effective and new treatments of renal fibrosis. PDGF: Platelet-derived growth factors; PAI1: plasminogen activator inhibitor-1; CTGF: connective tissue growth factor; DDR1: discoidin domain receptor 1; TGF $\beta$ : transforming growth factor- $\beta$; $N F \mathrm{k} B: n u c l e a r$ factor-кB; NADPH: nicotinamide adenine dinucleotide phosphate; mRNA: messenger ribonucleic acid.

TGF $\beta$ and aldosterone blockers or other agents are beneficial for combatting the progression of renal fibrosis, and to assess whether these therapies can actually be investigated in human clinical trials because it is evident that Ang II blockade alone is not sufficient for preventing or regressing renal fibrosis.

Yang and colleagues showed that the ability to block SMAD3 but not SMAD2, and to inhibit Ang II-mediated CTGF and fibrotic responses, may also be an alternative therapy for preventing the progression of renal fibrosis (30). It seems possible to inhibit matrix deposition and renal fibrosis within the kidney by blocking CTGF expression without affecting TGF $\beta$ expression. Furthermore, CTGF blockade promotes some anti-profibrotic properties similar to TGF $\beta$ blockade, however, it probably does not share the immunomodulatory properties of TGF $\beta$ (36). In another study, it was demonstrated that CTGF siRNA blocked the epithelial-mesenchymal transition in rat kidney grafts undergoing chronic allograft nephropathy (94). CTGF inhibition may be considered a potential therapy for preventing renal fibrosis.

Active vitamin D and its analogous elements reduce renal fibrosis by attenuating glomerulosclerosis and interstitial fibrosis. The various actions of active vitamin D on kidney function, depending on the nature and aetiologies of the CKD 
animal models, consist of the regulation of the reninangiotensin system, anti-inflammation, podocyte defence, hepatocyte growth factor induction and preservation of tubular epithelium by blocking epithelial-mesenchymal transition. Supplementary treatment with active vitamin D can thus improve renal function in individuals with CKD (73).

Treatment with vitamin E significantly reduced the degree of kidney structural damage in the 5/6 nephrectomized rats, showing that treatment with vitamin $\mathrm{E}$ reduces glomerulosclerosis in 5/6 nephrectomized rats (95). Perhaps this is associated with the fact that vitamin E somewhat attenuates the rise in glomerular and mesangial diacylglycerol content that mediates the overactivation of protein kinase $\mathrm{C}$ (primary mediator of renal dysfunction in diabetic rats). Vitamin E treatment also attenuates glomerular and mesangial TGF $\beta$ activity. Ruboxistaurin, a drug which inhibits this isoform of protein kinase $\mathrm{C}$, was tested in diabetic rats, and has been observed to reduce the mesangial expression of TGF $\beta$ mRNA and to some extent suppress glomerulosclerosis (2). In another study, Wang and colleagues showed that the Fuzheng Huayu formula and vitamin E have an inhibitory effect on renal fibrosis by reversing tubular epithelialmesenchymal transition in renal interstitial fibrosis induced by $\mathrm{HgCl}_{2}$ in rats. Additionally, the Fuzheng Huayu formula directly reduced TGF $\beta$-induced epithelial-mesenchymal transition in human proximal tubular epithelial cells. This action is probably potentiated, at least in part, by reducing SMAD2/3 phosphorylation (49). Indeed, it appears that in rats, vitamin $\mathrm{E}$ has a protective effect on $\mathrm{HgCl}_{2}$-induced renal interstitial fibrosis $(49,50)$. However, it is worth noting that a meta-analysis of 136,000 subjects in 19 clinical trials indicated that a high dosage (400 IU/day) of vitamin E supplements increased all-cause mortality in humans, limiting the efficacy of this treatment in humans (96).

Halofuginone, a collagen I inhibitor, showed a beneficial decrease in the progression of renal fibrosis in the experimental model of 5/6 renal mass ablation, and this was independent of blood pressure alterations (89).

The NFkB family can directly and indirectly stimulate cellular actions leading to tissue fibrosis. Cytokine-medicated counter-regulatory mechanisms that block NFkB activation might possibly prevent renal disease initiation/progression (15). Other types of treatment may concern the inhibition of NADPH oxidase activity, an important mediator of renal fibrosis. The use of agents with antioxidant properties appears to have benefits in the regression of renal fibrosis in nephropathy rats (2).

Extracellular factors and intracellular mediators that control epithelial-mesenchymal transition have been recognized as a possible alternatives in combat against the progression of renal fibrosis (13). Shin et al. suggest that treatment with small-molecule nuclear factor E2-related factor 2 (NRF2)-specific activators might be an alternative therapy for the prevention or regression of the epithelialmesenchymal transition fibrosis process evidenced by oxidative stress (97).

Collagen-receptor: discoidin domain receptor 1 (DDR1) is involved in the pathogenesis of Alport syndrome, including renal inflammation and fibrosis. The inhibition of this receptor seems to represent a new therapeutic strategy in the progression of renal fibrosis in the future. This nephroprotective effect on the loss of DDR1 may be due to the down-regulation of profibrotic cytokines TGF $\beta$ and CTGF (98).

Chaetomellic acid A, a selective inhibitor of HRAS farnesylation (99) tested in mice who had undergone UUO, showed a promising action on the reversal of renal fibrosis (100). In addition, our research team demonstrated that inhibition of RAS activation with chaetomellic acid A may be a future strategy in the prevention of renal fibrosis (101).

Another alternative treatment for renal fibrosis might be the use of stem or progenitor cells to treat or restore the function of the damaged kidney. This type of treatment allows us not only to halt the progression of the disease but also to restore renal function, however, we need to confirm several mechanisms of the stem or progenitor cell action (102).

It is currently thought that cultured cells with features of glomerular epithelial differentiation have an important action on the development of renal damage due to the effects of plasma proteins on podocyte function. In this way, proteins, beyond being a simple indicator of renal damage, can be toxic to the kidney (19).

Through latest-generation confocal and multiphoton microscopy, and with the help of computer programmes, we are able to identify differences within the glomerular network organization that emerge during sclerosis regression, which allows for the identification of changes in cell and gene expression (19). Despite the progress achieved in several studies with different types of treatments and drugs, no drugs presently exist for the effective treatment of renal fibrosis (25).

\section{Conclusion}

CKD has many different genetic and environmental causes and several pathological effects such as renal fibrosis, hence this is why it is very important to use different animal models. These models have provided important insight into the pathogenesis of renal fibrosis. The use of appropriate models for the study of renal fibrosis may provide information that provides an understanding of the pathogenic mechanisms of the causes and progression of the disease, as well as potential therapeutic interventions. In particular, the expansion of experimental models for renal fibrosis has allowed the productive investigation of factors associated with cellular and molecular responses to damage caused by renal disease and the fibrotic sequence of events. There is a variety of animal models which display characteristics and 
aspects of the relevant human renal disease. Among the many animal models used to study renal fibrosis, some are more commonly used than others and therefore there is little information available on the less-studied models. The most commonly used models to investigate renal fibrosis are UUO and 5/6 renal mass reduction, perhaps because they have more advantages and similarities to studies of renal fibrosis in humans, or simply because they have been the most used in recent years. On the other hand, in our research, we found that in many investigations, not all methods and materials are disclosed. For these reasons, many of the renal fibrosis models, especially those that are used less often, are very difficult to reproduce.

The most frequent pathophysiological changes in humans have been successfully reproduced in animal models, which increases our understanding of human pathology and enables us to develop new animal models and also evaluate new therapies. However, no model exactly mimics all the alterations caused by the progression of renal disease in humans such as renal fibrosis, because the factors associated with this disease are not yet completely understood. Due to the different aetiological factors of this disease, it is necessary to evaluate precise experimental data because the analysis of the results obtained in the animal models could lead to wrong conclusions about the pathophysiology of renal fibrosis in humans. Thus, the extrapolation of outcomes from animal models to humans should consider that the mechanisms of fibrosis and efficacy of interventions and treatments differ considerably with different models of renal fibrosis. Perhaps the greatest challenge is to understand how to adapt the experimental innovations to clinical reality. Currently, there are no effective treatments that prevent the progressive destruction of nephrons or avoid the formation of scar tissue. Nevertheless, the potential of the renin-angiotensin system in renal lesions that leads to ECM and sclerosis should be emphasized by the effectiveness of therapies that aim to inhibit its various actions. It is therefore important to improve our knowledge of the cellular and molecular stages of the development of renal fibrosis in order to determine specific markers that will allow for appropriate intervention in the progression of $\mathrm{CKD}$, and perhaps even achieve a regression/ elimination of renal sclerosis.

\section{Conflicts of Interest}

The Authors declare that they have no conflict of interests in regard to this study.

\section{Acknowledgements}

This work was supported in part by a project grant from the Fundação para a Ciência e Tecnologia, Ministério da Educação, Portugal (grant no. SFRH/PROTEC/67576/2010).
This work was supported by: European Investment Funds by FEDER/COMPETE/POCI- Operacional Competitiveness and Internacionalization Programme, under Project POCI-01-0145-FEDER016728 and National Funds by the Portuguese Foundation for Science and Technology (FTC), under the project PTDC/DTP-DES/6077/2014 and by European Investment Funds by FEDER/COMPETE/POCIOperacional Competitiveness and Internacionalization Programme, under Project POCI-01-0145-FEDER-006958 and National Funds by Portuguese Foundation for Science and Technology (FTC), under the project UID/AGR/04033/2013.

\section{References}

1 Lopez-Novoa JM, Martinez-Salgado C, Rodriguez-Pena AB and Lopez-Hernandez FJ: Common pathophysiological mechanisms of chronic kidney disease: Therapeutic perspectives. Pharmacol Ther 128(1): 61-81, 2010.

2 McCarty MF: Adjuvant strategies for prevention of glomerulosclerosis. Med Hypotheses 67(6): 1277-1296, 2006.

3 Chia TY, Sattar MA, Abdullah MH, Ahmad FUD, Ibraheem ZO, Li KJ, Pei YP, Rathore HA, Singh GKC, Abdullah NA and Johns EJ: Cyclosporine A-induced nephrotoxic Sprague-Dawley rats are more susceptable to altered vascular function and haemodynamics. Int J Pharm Pharm Sci 4(2): 431-439, 2012.

4 Zhao J, Wang H, Cao AL, Jiang MQ, Chen X and Peng W: Renal tubulointerstitial fibrosis: A review in animal models. J Integr Nephrol Androl 2(3): 75-80, 2015.

5 Fogo AB: Progression and potential regression of glomerulosclerosis. Kidney Int 59(2): 804-819, 2001.

6 Hewitson TD: Renal tubulointerstitial fibrosis: Common but never simple. Am J Physiol Renal Physiol 296(6): F1239-1244, 2009.

7 Rodriguez-Pena A, Prieto M, Duwel A, Rivas JV, Eleno N, Perez-Barriocanal F, Arevalo M, Smith JD, Vary CP, Bernabeu $\mathrm{C}$ and Lopez-Novoa JM: Up-regulation of endoglin, a TGF-betabinding protein, in rats with experimental renal fibrosis induced by renal mass reduction. Nephrol Dial Transplant 16(Suppl 1): 34-39, 2001.

$8 \mathrm{Yu}$ L, Noble NA and Border WA: Therapeutic strategies to halt renal fibrosis. Curr Opin Pharmacol 2(2): 177-181, 2002.

9 Liu WH, Tang NN and Zhang QD: Could mycophenolate mofetil combined with benazapril delay tubulointerstitial fibrosis in 5/6 nephrectomized rats? Chin Med J 122(2): 199-204, 2009.

10 el Nahas AM, Muchaneta-Kubara EC, Essawy $M$ and Soylemezoglu O: Renal fibrosis: Insights into pathogenesis and treatment. Int J Biochem Cell Biol 29(1): 55-62, 1997.

11 Gupta S, Clarkson MR, Duggan J and Brady HR: Connective tissue growth factor: Potential role in glomerulosclerosis and tubulointerstitial fibrosis. Kidney Int 58(4): 1389-1399, 2000.

12 Kagami S, Border WA, Miller DE and Noble NA: Angiotensin-II stimulates extracellular-matrix protein-synthesis through induction of transforming growth-factor-beta expression in rat glomerular mesangial cells. J Clin Invest 93(6): 2431-2437, 1994.

13 Liu Y: New insights into epithelial-mesenchymal transition in kidney fibrosis. J Am Soc Nephrol 21(2): 212-222, 2010.

14 Branton MH and Kopp JB: TGF-beta and fibrosis. Microbes Infect 1(15): 1349-1365, 1999.

15 Klahr S and Morrissey JJ: The role of vasoactive compounds, growth factors and cytokines in the progression of renal disease. Kidney Int Suppl 7: S7-14, 2000. 
16 Kaissling B, Lehir M and Kriz W: Renal epithelial injury and fibrosis. Biochim Biophys Acta 1832(7): 931-939, 2013.

17 Chevalier RL, Forbes MS and Thornhill BA: Ureteral obstruction as a model of renal interstitial fibrosis and obstructive nephropathy. Kidney Int 75(11): 1145-1152, 2009.

18 Xue JL, Ma JZ, Louis TA and Collins AJ: Forecast of the number of patients with end-stage renal disease in the United States to the year 2010. J Am Soc Nephrol 12(12): 2753-2758, 2001.

19 Remuzzi G, Benigni A and Remuzzi A: Mechanisms of progression and regression of renal lesions of chronic nephropathies and diabetes. J Clin Invest 116(2): 288-296, 2006.

20 Gagliardini E and Benigni A: Role of anti-TGF-beta antibodies in the treatment of renal injury. Cytokine Growth Factor Rev 17(1-2): 89-96, 2006.

21 Lysaght MJ: Maintenance dialysis population dynamics: Current trends and long-term implications. J Am Soc Nephrol 13(Suppl 1): S37-40, 2002.

22 Gilbertson DT, Liu J, Xue JL, Louis TA, Solid CA, Ebben JP and Collins AJ: Projecting the number of patients with end-stage renal disease in the United States to the year 2015. J Am Soc Nephrol 16(12): 3736-3741, 2005.

23 Yang HC, Zuo Y and Fogo AB: Models of chronic kidney disease. Drug Discov Today Dis Models 7(1-2): 13-19, 2010.

24 Nath KA: Tubulointerstitial changes as a major determinant in the progression of renal damage. Am J Kidney Dis 20(1): 1-17, 1992

25 Al-Bayati MA, Xie Y, Mohr FC, Margolin SB and Giri SN: Effect of pirfenidone against vanadate-induced kidney fibrosis in rats. Biochem Pharmacol 64(3): 517-525, 2002.

26 Cohen EP: Fibrosis causes progressive kidney failure. Med Hypotheses 45(5): 459-462, 1995.

27 Cattran DC and Rao P: Long-term outcome in children and adults with classic focal segmental glomerulosclerosis. Am J Kidney Dis 32(1): 72-79, 1998.

28 Pei Y, Cattran D, Delmore T, Katz A, Lang A and Rance P: Evidence suggesting under-treatment in adults with idiopathic focal segmental glomerulosclerosis. Regional glomerulonephritis registry study. Am J Med 82(5): 938-944, 1987.

29 Appenroth D, Lupp A, Kriegsmann J, Sawall S, Splinther J, Sommer M, Stein G and Fleck C: Temporary warm ischaemia, 5/6 nephrectomy and single uranyl nitrate administration-comparison of three models intended to cause renal fibrosis in rats. Exp Toxicol Pathol 53(4): 316-324, 2001.

30 Yang F, Chung AC, Huang XR and Lan HY: Angiotensin II induces connective tissue growth factor and collagen I expression via transforming growth factor-beta-dependent and independent smad pathways: The role of SMAD3. Hypertension 54(4): 877-884, 2009.

31 Klahr S and Morrissey J: Obstructive nephropathy and renal fibrosis. Am J Physiol Renal Physiol 283(5): F861-875, 2002.

32 Border WA and Noble NA: Interactions of transforming growth factor-beta and angiotensin II in renal fibrosis. Hypertension 31(1 Pt 2): 181-188, 1998.

33 Matsusaka $\mathrm{T}$, Hymes $\mathrm{J}$ and Ichikawa $\mathrm{I}$ : Angiotensin in progressive renal diseases: Theory and practice. J Am Soc Nephrol 7(10): 2025-2043, 1996.

34 Meran S and Steadman R: Fibroblasts and myofibroblasts in renal fibrosis. Int J Exp Pathol 92(3): 158-167, 2011.

35 Efstratiadis G, Divani M, Katsioulis E and Vergoulas G: Renal fibrosis. Hippokratia 13(4): 224-229, 2009.
36 Phanish MK, Winn SK and Dockrell ME: Connective tissue growth factor-(cTGF, CCN2)-a marker, mediator and therapeutic target for renal fibrosis. Nephron Exp Nephrol 114(3): e83-92, 2010.

37 Rodrigues Diez R, Rodrigues-Diez R, Lavoz C, Rayego-Mateos S, Civantos E, Rodriguez-Vita J, Mezzano S, Ortiz A, Egido J and Ruiz-Ortega M: Statins inhibit angiotensin II/SMAD pathway and related vascular fibrosis, by a TGF-betaindependent process. PLoS One 5(11): e14145, 2010.

38 Baeuerle PA and Henkel T: Function and activation of NF-kappa $B$ in the immune system. Annu Rev Immunol 12: 141-179, 1994.

39 Lee KS, Buck M, Houglum K and Chojkier M: Activation of hepatic stellate cells by TGF alpha and collagen type I is mediated by oxidative stress through c-MYB expression. J Clin Invest 96(5): 2461-2468, 1995.

40 Liu Y: Cellular and molecular mechanisms of renal fibrosis. Nat Rev Nephrol 7(12): 684-696, 2011.

41 Lin SL, Kisseleva T, Brenner DA and Duffield JS: Pericytes and perivascular fibroblasts are the primary source of collagenproducing cells in obstructive fibrosis of the kidney. Am J Pathol 173(6): 1617-1627, 2008.

42 Hayslett JP, Kashgarian M and Epstein FH: Functional correlates of compensatory renal hypertrophy. J Clin Invest 47(4): 774799, 1968.

43 Lee BC, Choi JB, Cho HJ and Kim YS: Rehmannia glutinosa ameliorates the progressive renal failure induced by $5 / 6$ nephrectomy. J Ethnopharmacol 122(1): 131-135, 2009.

44 Wang PH, Cenedeze MA, Campanholle G, Malheiros DM, Torres HA, Pesquero JB, Pacheco-Silva A and Camara NO: Deletion of bradykinin B1 receptor reduces renal fibrosis. Int Immunopharmacol 9(6): 653-657, 2009.

45 Bing P, Maode L, Li F and Sheng H: Expression of renal transforming growth factor-beta and its receptors in a rat model of chronic cyclosporine-induced nephropathy. Transplant Proc 38(7): 2176-2179, 2006.

46 Fassi A, Sangalli F, Maffi R, Colombi F, Mohamed EI, Brenner BM, Remuzzi G and Remuzzi A: Progressive glomerular injury in the MWF rat is predicted by inborn nephron deficit. J Am Soc Nephrol 9(8): 1399-1406, 1998.

47 Le Berre L, Godfrin Y, Perretto S, Smit H, Buzelin F, Kerjaschki D, Usal C, Cuturi C, Soulillou JP and Dantal J: The Buffalo/Mna rat, an animal model of FSGS recurrence after renal transplantation. Transplant Proc 33(7-8): 3338-3340, 2001.

48 Ucero AC, Benito-Martin A, Fuentes-Calvo I, Santamaria B, Blanco J, Lopez-Novoa JM, Ruiz-Ortega M, Egido J, Burkly LC, Martinez-Salgado C and Ortiz A: TNF-related weak inducer of apoptosis (TWEAK) promotes kidney fibrosis and RASdependent proliferation of cultured renal fibroblast. Biochim Biophys Acta 1832(10): 1744-1755, 2013.

49 Wang QL, Yuan JL, Tao YY, Zhang Y, Liu P and Liu CH: Fuzheng huayu recipe and vitamin $\mathrm{E}$ reverse renal interstitial fibrosis through counteracting TGF-beta 1-induced epithelial-tomesenchymal transition. J Ethnopharmacol 127(3): 631-640, 2010.

50 Tao YY, Wang QL, Yuan JL, Shen L and Liu CH: Effects of vitamin $\mathrm{E}$ on mercuric chloride-induced renal interstitial fibrosis in rats and the antioxidative mechanism. Zhong Xi Yi Jie He Xue Bao 9(2): 201-208, 2011.

51 Bridges CC, Joshee L and Zalups RK: Aging and the disposition and toxicity of mercury in rats. Exp Gerontol 53: 31-39, 2014. 
52 Al-Bayati MA, Giri SN, Raabe OG, Rosenblatt LS and Shifrine M: Time and dose-response study of the effects of vanadate on rats: Morphological and biochemical changes in organs. J Environ Pathol Toxicol Oncol 9(5-6): 435-455, 1989.

53 Wang Y, Wang YP, Tay YC and Harris DC: Progressive adriamycin nephropathy in mice: Sequence of histologic and immunohistochemical events. Kidney Int 58(4): 1797-1804, 2000.

54 Tan RJ, Zhou L, Zhou D, Lin L and Liu Y: Endothelin receptor A blockade is an ineffective treatment for adriamycin nephropathy. PLoS One 8(11): e79963, 2013

55 Silveira KD, Barroso LC, Vieira AT, Cisalpino D, Lima CX, Bader M, Arantes RM, Dos Santos RA, Simoes ESAC and Teixeira MM: Beneficial effects of the activation of the angiotensin-(1-7) MAS receptor in a murine model of adriamycin-induced nephropathy. PLoS One 8(6): e66082, 2013.

56 Haley DP, Bulger RE and Dobyan DC: The long-term effects of uranyl nitrate on the structure and function of the rat kidney. Virchows Arch B Cell Pathol Incl Mol Pathol 41(1-2): 181-192, 1982.

57 Yuan HT, Li XZ, Pitera JE, Long DA and Woolf AS: Peritubular capillary loss after mouse acute nephrotoxicity correlates with down-regulation of vascular endothelial growth factor-A and hypoxia-inducible factor-1 alpha. Am J Pathol 163(6): 22892301, 2003

58 Miric G, Dallemagne C, Endre Z, Margolin S, Taylor SM and Brown L: Reversal of cardiac and renal fibrosis by pirfenidone and spironolactone in streptozotocin-diabetic rats. $\mathrm{Br} \mathrm{J}$ Pharmacol 133(5): 687-694, 2001.

59 Nielsen FT, Jensen BL, Hansen PB, Marcussen N and Bie P: The mineralocorticoid receptor antagonist eplerenone reduces renal interstitial fibrosis after long-term cyclosporine treatment in rat: Antagonizing cyclosporine nephrotoxicity. BMC Nephrol 14: 42, 2013

60 Kim JY, Ghee JY, Lim SW, Piao SG, Chung BH, Yoon HE, Hwang HS, Choi BS, Kim J and Yang CW: Comparison of early and late conversion of sirolimus in experimental model of chronic cyclosporine nephropathy. J Korean Med Sci 27(2): 160$169,2012$.

61 Rossini M, Naito T, Yang H, Freeman M, Donnert E, Ma LJ, Dunn SR, Sharma K and Fogo AB: Sulodexide ameliorates early but not late kidney disease in models of radiation nephropathy and diabetic nephropathy. Nephrol Dial Transplant 25(6): 18031810,2010

62 Shimamura $\mathrm{T}$ and Morrison $\mathrm{AB}$ : A progressive glomerulosclerosis occurring in partial five-sixths nephrectomized rats Am J Pathol 79(1): 95-106, 1975.

63 Chow K-M, Liu Z-C and Chang TM-S: Animal remnant kidney model of chronic renal failure revisited. Hong Kong J Nephroly 5(2): 57-64, 2003

64 Hostetter TH, Olson JL, Rennke HG, Venkatachalam MA and Brenner BM: Hyperfiltration in remnant nephrons: A potentially adverse response to renal ablation. J Am Soc Nephrol 12(6): 1315-1325, 2001.

$65 \mathrm{Ma}$ LJ and Fogo AB: Model of robust induction of glomerulosclerosis in mice: Importance of genetic background Kidney Int 64(1): 350-355, 2003.

66 Wang Q, Hummler E, Nussberger J, Clement S, Gabbiani G, Brunner HR and Burnier M: Blood pressure, cardiac, and renal responses to salt and deoxycorticosterone acetate in mice: Role of renin genes. J Am Soc Nephrol 13(6): 1509-1516, 2002.
67 Schwartz MM, Bidani AK and Lewis EJ: Glomerular epithelial cell function and pathology following extreme ablation of renal mass. Am J Pathol 126(2): 315-324, 1987.

68 Griffin KA, Picken MM, Churchill M, Churchill P and Bidani AK: Functional and structural correlates of glomerulosclerosis after renal mass reduction in the rat. J Am Soc Nephrol 11(3): 497-506, 2000.

69 Fleck C, Appenroth D, Jonas P, Koch M, Kundt G, Nizze H and Stein G: Suitability of 5/6 nephrectomy $(5 / 6 n x)$ for the induction of interstitial renal fibrosis in rats-influence of sex, strain, and surgical procedure. Exp Toxicol Pathol 57(3): 195-205, 2006.

70 Benfield MR, McDonald RA, Bartosh S, Ho PL and Harmon W: Changing trends in pediatric transplantation: 2001 Annual Report of the North American Pediatric Renal Transplant Cooperative study. Pediatr Transplant 7(4): 321-335, 2003.

71 Mendelsohn C: Functional obstruction: The renal pelvis rules. J Clin Invest 113(7): 957-959, 2004.

72 Grande MT, Perez-Barriocanal F and Lopez-Novoa JM: Role of inflammation in tubulo-interstitial damage associated to obstructive nephropathy. J Inflamm (Lond) 7: 19, 2010.

73 Tan X, Li Y and Liu Y: Therapeutic role and potential mechanisms of active vitamin D in renal interstitial fibrosis. $\mathrm{J}$ Steroid Biochem Mol Biol 103(3-5): 491-496, 2007.

74 Klein J, Gonzalez J, Duchene J, Esposito L, Pradere JP, Neau E, Delage C, Calise D, Ahluwalia A, Carayon P, Pesquero JB, Bader M, Schanstra JP and Bascands JL: Delayed blockade of the kinin $\mathrm{B} 1$ receptor reduces renal inflammation and fibrosis in obstructive nephropathy. FASEB J 23(1): 134-142, 2009.

75 Satoh M, Kashihara N, Yamasaki Y, Maruyama K, Okamoto K, Maeshima Y, Sugiyama H, Sugaya T, Murakami K and Makino $\mathrm{H}$ : Renal interstitial fibrosis is reduced in angiotensin II type 1A receptor-deficient mice. J Am Soc Nephrol 12(2): 317-325, 2001.

76 Kellner D, Chen J, Richardson I, Seshan SV, El Chaar M, Vaughan ED, Jr., Poppas D and Felsen D: Angiotensin receptor blockade decreases fibrosis and fibroblast expression in a rat model of unilateral ureteral obstruction. J Urol 176(2): 806-812, 2006.

77 Humphreys BD, Lin SL, Kobayashi A, Hudson TE, Nowlin BT, Bonventre JV, Valerius MT, McMahon AP and Duffield JS: Fate tracing reveals the pericyte and not epithelial origin of myofibroblasts in kidney fibrosis. Am J Pathol 176(1): 85-97, 2010.

78 Liu M, Agreda P, Crow M, Racusen L and Rabb H: Effects of delayed rapamycin treatment on renal fibrosis and inflammation in experimental ischemia reperfusion injury. Transplant Proc 41(10): 4065-4071, 2009.

79 Takada M, Nadeau KC, Shaw GD and Tilney NL: Prevention of late renal changes after initial ischemia/reperfusion injury by blocking early selectin binding. Transplantation 64(11): 1520$1525,1997$.

80 Melin J, Hellberg O, Akyurek LM, Kallskog O, Larsson E and Fellstrom BC: Ischemia causes rapidly progressive nephropathy in the diabetic rat. Kidney Int 52(4): 985-991, 1997.

81 Hartner A, Cordasic N, Klanke B, Veelken R and Hilgers KF: Strain differences in the development of hypertension and glomerular lesions induced by deoxycorticosterone acetate salt in mice. Nephrol Dial Transplant 18(10): 1999-2004, 2003.

82 Nakamura T, Oite T, Shimizu F, Matsuyama M, Kazama T, Koda $\mathrm{Y}$ and Arakawa M: Sclerotic lesions in the glomeruli of Buffalo/Mna rats. Nephron 43(1): 50-55, 1986. 
83 Remuzzi A, Puntorieri S, Alfano M, Macconi D, Abbate M, Bertani T and Remuzzi G: Pathophysiologic implications of proteinuria in a rat model of progressive glomerular injury. Lab Invest 67(5): 572-579, 1992.

84 Matsusaka T, Xin J, Niwa S, Kobayashi K, Akatsuka A, Hashizume H, Wang QC, Pastan I, Fogo AB and Ichikawa I: Genetic engineering of glomerular sclerosis in the mouse via control of onset and severity of podocyte-specific injury. J Am Soc Nephrol 16(4): 1013-1023, 2005.

85 Dickie P, Felser J, Eckhaus M, Bryant J, Silver J, Marinos N and Notkins AL: Hiv-associated nephropathy in transgenic mice expressing HIV-1 genes. Virology 185(1): 109-119, 1991.

86 Ray PE: Can we cure HIV-1-associated nephropathy in transgenic mice? Kidney Int 81(9): 811-813, 2012.

87 Sugaya T, Nishimatsu S, Tanimoto K, Takimoto E, Yamagishi T, Imamura $\mathrm{K}$, Goto $\mathrm{S}$, Imaizumi $\mathrm{K}$, Hisada $\mathrm{Y}$, Otsuka $\mathrm{A}$ and Uchida H, Sugiura M, Fukuta K, Fukamizu A and Murakami $\mathrm{K}$ : Angiotensin II type $1 \mathrm{~A}$ receptor-deficient mice with hypotension and hyperreninemia. J Biol Chem 270(32): 18719$18722,1995$.

88 Diah S, Zhang GX, Nagai Y, Zhang W, Gang L, Kimura S, Hamid MR, Tamiya T, Nishiyama A and Hitomi H: Aldosterone induces myofibroblastic transdifferentiation and collagen gene expression through the rho-kinase dependent signaling pathway in rat mesangial cells. Exp Cell Res 314(20): 3654-3662, 2008.

89 Benchetrit S, Yarkoni S, Rathaus M, Pines M, Rashid G and Bernheim J: Halofuginone reduces the occurrence of renal fibrosis in 5/6 nephrectomized rats. Isr Med Assoc J 9(1): 3034, 2007.

90 Boor P, Sebekova K, Ostendorf T and Floege J: Treatment targets in renal fibrosis. Nephrol Dial Transplant 22(12): 33913407, 2007.

91 Ishikawa A, Tanaka M, Ohta N, Ozono S and Kitamura T: Prevention of interstitial fibrosis of renal allograft by angiotensin II blockade. Transplant Proc 38(10): 3498-3501, 2006.

92 Shimizu T, Kuroda T, Hata S, Fukagawa M, Margolin SB and Kurokawa K: Pirfenidone improves renal function and fibrosis in the post-obstructed kidney. Kidney Int 54(1): 99-109, 1998.

93 Sun GP, Kohno M, Guo P, Nagai Y, Miyata K, Fan YY, Kimura S, Kiyomoto H, Ohmori K, Li DT, Abe Y and Nishiyama A: Involvements of rho-kinase and TGF-beta pathways in aldosterone-induced renal injury. J Am Soc Nephrol 17(8): 2193-2201, 2006.

94 Luo GH, Lu YP, Song J, Yang L, Shi YJ and Li YP: Inhibition of connective tissue growth factor by small interfering RNA prevents renal fibrosis in rats undergoing chronic allograft nephropathy. Transplant Proc 40(7): 2365-2369, 2008.

95 Tain YL, Freshour G, Dikalova A, Griendling K and Baylis C: Vitamin $\mathrm{E}$ reduces glomerulosclerosis, restores renal neuronal NOS, and suppresses oxidative stress in the 5/6 nephrectomized rat. Am J Physiol Renal Physiol 292(5): F1404-1410, 2007.
96 Miller ER, 3rd, Pastor-Barriuso R, Dalal D, Riemersma RA, Appel LJ and Guallar E: Meta-analysis: High-dosage vitamin E supplementation may increase all-cause mortality. Ann Intern Med 142(1): 37-46, 2005.

97 Shin DH, Park HM, Jung KA, Choi HG, Kim JA, Kim DD, Kim SG, Kang KW, Ku SK, Kensler TW and Kwak MK: The NRF2heme oxygenase-1 system modulates cyclosporin A-induced epithelial-mesenchymal transition and renal fibrosis. Free Radic Biol Med 48(8): 1051-1063, 2010.

98 Gross O, Girgert R, Beirowski B, Kretzler M, Kang HG, Kruegel J, Miosge N, Busse AC, Segerer S, Vogel WF, Muller GA and Weber M: Loss of collagen-receptor DDR1 delays renal fibrosis in hereditary type IV collagen disease. Matrix Biol 29(5): 346-356, 2010.

99 Ruocco A, Santillo M, Cicale M, Seru R, Cuda G, Anrather J, Iadecola C, Postiglione A, Avvedimento EV and Paterno R: Farnesyl transferase inhibitors induce neuroprotection by inhibiting ha-RAS signalling pathway. Eur J Neurosci 26(11): 3261-3266, 2007.

100 Rodriguez-Pena AB, Fuentes-Calvo I, Docherty NG, Arevalo M, Grande MT, Eleno N, Perez-Barriocanal F and Lopez-Novoa JM: Effect of angiotensin II and small GTPase RAS signaling pathway inhibition on early renal changes in a murine model of obstructive nephropathy. Biomed Res Int 2014: 124902, 2014.

101 Nogueira A, Vala H, Nobrega C, Pires CA, Colaço B, Oliveira PA and Pires MJ: Effect of chronic therapy with chaethomellic acid A on renal fibrosis in 5/6 nephrectomized rats: A preliminary study. Virchows Archiv 467: S32-S32, 2015.

102 Schachinger V and Zeiher AM: Stem cells and cardiovascular and renal disease: Today and tomorrow. J Am Soc Nephrol 16(Suppl 1): S2-6, 2005.

103 Shi SH, Zheng SS, Jia CK, Zhu YF and Xie HY: Inhibitory effect of tea polyphenols on transforming growth factor-beta1 expression in rat with cyclosporine A-induced chronic nephrotoxicity. Acta Pharmacol Sin 25(1): 98-103, 2004.

104 Nelson PJ, D'Agati VD, Gries JM, Suarez JR and Gelman IH: Amelioration of nephropathy in mice expressing HIV-1 genes by the cyclin-dependent kinase inhibitor flavopiridol. J Antimicrob Chemother 51(4): 921-929, 2003. 